Leibniz-Institut für

Wirtschaftsforschung

Halle

\title{
Public Bank Guarantees and Allocative Efficiency
}

Reint E. Gropp

Andre Guettler

Vahid Saadi

June 2015

No. 7

IWH-DISKUSSIONSPAPIERE IWH DISCUSSION PAPERS 
Authors: Reint E. Gropp

President

Halle Institute for Economic Research (IWH) -

Member of the Leibniz Association

E-mail: president@iwh-halle.de

Andre Guettler

Ulm University

Institute of Strategic Management and Finance

E-mail: andre.guettler@uni-ulm.de

Vahid Saadi

Goethe University Frankfurt am Main

House of Finance

E-mail: vahid.saadi@hof.uni-frankfurt.de

Financial support by the German Science Foundation (DFG, GR3596/3-1) is gratefully acknowledged.

The responsibility for discussion papers lies solely with the individual authors. The views expressed herein do not necessarily represent those of the IWH. The papers represent preliminary work and are circulated to encourage discussion with the authors. Citation of the discussion papers should account for their provisional character; a revised version may be available directly from the authors.

Comments and suggestions on the methods and results presented are welcome.

IWH Discussion Papers are indexed in RePEc-EconPapers and in ECONIS.

Editor:

Halle Institute for Economic Research (IWH) - Member of the Leibniz Association

Address: $\quad$ Kleine Maerkerstrasse 8, D-06108 Halle (Saale), Germany

Postal Address: P.O. Box 1103 61, D-06017 Halle (Saale), Germany

Phone: $\quad$ +49 $\quad+445775360$

Fax: $\quad+493457753820$

Internet: $\quad$ www.iwh-halle.de

ISSN $1860-5303$ (Print)

ISSN 2194-2188 (Online) 


\title{
Public Bank Guarantees and Allocative Efficiency
}

\begin{abstract}
In the wake of the recent financial crisis, many governments extended public guarantees to banks. We take advantage of a natural experiment, in which long-standing public guarantees were removed for a set of German banks following a lawsuit, to identify the real effects of these guarantees on the allocation of credit ("allocative efficiency"). Using matched bank/firm data, we find that public guarantees reduce allocative efficiency. With guarantees in place, poorly performing firms invest more and maintain higher rates of sales growth. Moreover, firms produce less efficiently in the presence of public guarantees. Consistently, we show that guarantees reduce the likelihood that firms exit the market. These findings suggest that public guarantees hinder restructuring activities and prevent resources to flow to the most productive uses.
\end{abstract}

Keywords: banking, public guarantees, allocative efficiency

JEL Classification: D22, D61, G21, G28, G31, G32 


\section{Staatliche Bankgarantien und Allokationseffizienz}

\section{Zusammenfassung}

Im Zuge der jüngsten Finanzkrise haben viele Regierungen ihre staatlichen Garantien für Banken erweitert. Wir nutzen ein natürliches Experiment, bei dem langjährige staatliche Garantien für eine Reihe deutscher Banken nach einem Rechtsstreit aufgehoben wurden, um die realwirtschaftlichen Auswirkungen dieser Bürgschaften auf die Kreditvergabe identifizieren zu können (,Allokationseffizienz“). Unter Verwendung zusammengeführter Bank- und Unternehmensdaten zeigt sich, dass staatliche Garantien diese Allokationseffizienz mindern. Werden Garantien gewährleistet, investieren leistungsschwache Unternehmen mehr und behalten höhere Zuwachsraten beim Umsatz bei. Darüber hinaus produzieren Unternehmen im Allgemeinen weniger effizient, wenn staatliche Garantien existieren. Folgerichtig zeigen wir außerdem, dass Garantien die Wahrscheinlichkeit verringern, dass Unternehmen aus dem Markt ausscheiden. Die Ergebnisse belegen, dass staatliche Garantien Restrukturierungsaktivitäten behindern und verhindern, dass finanzielle Mittel den produktivsten Verwendungszwecken zugeführt werden.

Schlagwörter: Bankwesen, staatliche Garantien, Allokationseffizienz

JEL-Klassifikation: D22, D61, G21, G28, G31, G32 


\section{Introduction}

In the wake of the 2007-09 financial crisis, many governments nationalized financial institutions, and/or extended blanket guarantees for the banking system. ${ }^{1}$ There is ample evidence that public guarantees affect the risk taking incentives of banks (see for example Boyd and Runkle (1993); Boyd and Gertler (1994); Sapienza (2004); Gropp, Hakenes, and Schnabel (2011); Gropp, Gruendl, and Guettler (2014)), but little is known about the long term effects of public guarantees on the allocation of capital and the dynamics of firm growth. The question we address in this paper is whether the distortions to banks' credit decisions induced by public guarantees have an impact on the allocation of capital and the efficiency of the corporate sector.

We examine the question against the backdrop of a class of standard moral hazard models in banking. In these models, public guarantees exacerbate moral hazard on the side of the lender (reduction in screening and monitoring effort as in Freixas and Rochet (1997), Boot and Greenbaum (1993), Dewatripont and Tirole (1993) and Matutes and Vives (1995)) and the borrower (investment in negative NPV projects, as in Jensen and Meckling (1976), Dewatripont and Maskin (1995), Corsetti, Pesenti and Roubini (1999) and Carletti, Cerasi and Daltung (2007)). This may result in a misallocation of capital, where poor projects and firms are funded and good projects and firms are not. We are building on King and Levine (1993) who emphasize the role of the financial system for growth in the spirit of Schumpeter (1942). In Schumpeter's (1942) creative destruction hypothesis growth takes place through waves of innovation. These waves of innovation generate new more efficient industries, which replace the inefficient existing ones. Innovative entry by entrepreneurs is the disruptive force that sustains economic growth

\footnotetext{
${ }^{1}$ In the U.S.: Indy Mac, Fannie Mae, Freddy Mac; UK: Bradford Bingley, Northern Rock, RBS, HBOS, Lloyds; Germany: IKB, Hypo Real Estate; Belgium/Netherlands: Dexia, Fortis and many others. See for example Gropp, Gruendl, and Guettler (2014).
} 
even as it destroys the value of established companies. Financial institutions play a central role in this process, because they evaluate projects and fund only those that ultimately increase productivity and cut funding to those that do not. Hence, in this paper we are interested in to which extent public guarantees may affect the process of economic growth described by the nexus of finance and entrepreneurship.

Identification of the effects of public guarantees on capital allocation is tricky for at least three reasons. One, in most cases, guarantees are granted in the midst of a crisis, in which case the allocative effects of the guarantees would be confounded by the allocative effects of the crisis itself. This paper takes advantage of a natural experiment to tackle this identification problem. ${ }^{2}$ We study the question in the context of a lawsuit that removed guarantees for a large number of German savings banks in 2001. The judges ordered that the guarantees be discontinued, as they were deemed to be in violation of European anti- subsidy rules. Hence, the guarantees and their removal constitute an exogenous event from the perspective of the banks, unrelated to their stability or to their systemic importance and not prompted by any financial instability. ${ }^{3}$

Second, when examining the effect of public guarantees one is often faced with the problem of a suitable control group. Guarantees tend to be extended to the largest, most important banks in a country. Comparing the behavior of these banks to those not affected by the guarantee may lead to biased results. In this paper, the guarantees were extended to a large number of small to medium size banks, most of which are not systemically important. In addition, these banks compete both with very small cooperative banks, as well as with large internationally operating commercial banks, some of which may have benefited from an implicit guarantee. Hence, it is

\footnotetext{
${ }^{2}$ The same experiment was used in Fischer, Hainz, Rocholl, and Steffen (2011), Schnabel and Körner (2012) and Gropp, Gruendl, and Guettler (2014).

${ }^{3}$ We describe the institutional setting in more detail in Section 2 below.
} 
relatively straightforward to define control groups in this setting. ${ }^{4}$

We examine the research question using firm level and sector level data. First, we show in an annual sample of individual firms that in the presence of guarantees poorly performing firms invest more and show higher sales growth than in the absence of guarantees. In addition, we estimate the technological efficiency of firms directly based on Greene (2008), and show that with guarantees in place technologically inefficient firms have better access to funding. This is consistent with less careful screening and monitoring of borrowers by banks that benefit from guarantees. It suggests that guarantees may keep poorly performing firms in the market and may prevent more efficient competitors from entering. Hence, public guarantees not only distort the competitive interaction between banks (Gropp, Hakenes and Schnabel (2011)), but also the competitive interaction in the corporate sector. Consistent with this micro evidence, we show public guarantees reduce both firm birth and death rates. Overall, the findings suggest that guarantees result in a significant misallocation of capital, may prevent entry of more efficient firms into markets, and hinder restructuring activities in the corporate sector. While we do not directly examine the consequences for growth, the evidence is consistent with a growth reducing effect of public guarantees.

The paper builds on a body of literature that examines the effects of finance, financial regulation and financial intermediation on corporate outcomes and growth, although we are the first to examine the effect of public guarantees. Black and Strahan (2002) show that deregulation in the financial intermediation industry, namely the deregulation of US branching restrictions, improves the supply of credit to relationship borrowers and further increases the rate of new incorporations.

\footnotetext{
${ }^{4}$ Note also that we need to disentangle changes in allocative efficiency over the business cycle from the effects we are interested in the time series. This is also tricky but can be addressed well in our setup as we discuss below.
} 
Jayaratne and Strahan (1996) show that the relaxation of bank branch restrictions in the U.S. increased the rates of (per capita) growth. They further show that improvements in the quality of bank lending, not increased volume of bank lending, appear to be responsible for their main findings. For Europe, Bertrand, Schoar, and Thesmar (2007) analyze the deregulation of the French banking industry in the 1980s. They find that firms in more bank-dependent sectors are more likely to restructure after deregulation. Furthermore, they observe an increase in asset and job reallocation at the industry level, an improvement in allocative efficiency across firms, and a decline in concentration. ${ }^{5}$

\section{Institutional Background}

The German banking market is almost evenly split between three sets of banks: the savings bank sector (the focus of this paper), the cooperatives bank sector, and commercial banks. ${ }^{6}$ At the end of our sample period in 2006, it was characterized by a relatively low level of concentration with 452 savings banks, more than 1,000 credit cooperatives, and around 300 privately owned commercial banks. Taken as a group, savings banks in Germany had more than euro 1 trillion in total assets and 22,000 branches. German savings banks focus on traditional banking business with virtually no off-balance-sheet operations. Their main financing source is customer deposits, which they transform into loans to households and small and medium sized enterprises. Savings

\footnotetext{
${ }^{5}$ The paper is also related to the finance and growth literature more generally. Rajan and Zingales (1998) investigate whether industrial sectors that are relatively more in need of external finance develop disproportionately faster in countries with more-developed financial markets. They find evidence for this relationship in a large set of countries over the 1980's. Cetorelli and Gambera (2001) find evidence on the negative effects of bank concentration on growth. Moreover, Claessens and Laeven (2005) show that higher banking competition, which can be attributed to more financial development, is also associated with higher economic growth rates. Our paper also relates to the "evergreening" and zombie lending literature pioneered by Peek and Rosengren (2005) who show that banks may choose to distort lending towards the weakest firms in order to save them from bankruptcy, which in-turn prevents the realization of losses on their own balance sheets.

${ }^{6}$ For an in depth description of the German banking market, see Hackethal (2004).
} 
banks are owned by the local government of the community they operate in.

One important difference between savings banks and other banks is that they do not compete with each other, as a regional separation applies: Each savings bank uniquely serves its local market. Each savings bank is affiliated with one federal state bank ("Landesbank") and each federal state bank is affiliated with a state ("Bundesland") or group of states. The affiliated savings banks each own a part of their federal state bank. The federal state banks act as regional clearing houses for liquidity and facilitate the transfer of liquidity from savings banks with excess liquidity to those with liquidity shortfalls. In addition, the federal state banks secure market funding through the issuance of bonds. Federal state banks are largely internationally operating wholesale and investment banks (they are not allowed to lend to individuals, for example) and hence follow a fundamentally different business model from savings banks (e.g., Hau and Thum (2009); Puri, Rocholl, and Steffen (2011)). They are not included in this paper.

Despite unique governance structure, savings banks look quite similar to small commercial banks in continental Europe. They are on average relatively profitable: average pre-tax ROE is $12.8 \%$. The average cost to income ratio is $82.1 \%$. Pre-tax ROE of commercial banks is $12.1 \%$ in continental Europe and 13.2\% in the UK (317 banks, 1996-2004, data is from Bankscope). Similarly, cost to income ratios are $80.1 \%$ in continental Europe and $66.8 \%$ in the UK. Overall, savings banks look like a fairly typical and moderately inefficient small commercial bank in continental Europe. 


\section{Empirical Strategy and Data}

\subsection{Empirical Strategy}

The main objective of this paper is to analyze how public bank guarantees affect allocative efficiency. We are following Bertrand, Schoar, and Thesmar (2007) in defining allocative efficiency: It is allocative efficient, if efficient firms are able to obtain the funding they need to finance their investments while inefficient firms are cut off from external funding and ultimately exit. To be able to identify the effects, we examine individual firms and sectors that differ in how dependent they are on credit coming from banks that enjoyed a public guarantee.

The removal of government guarantees for German savings banks in 2001 serves as our first main plank of identification. Until the year 2000, the entire German savings bank sector was protected by government guarantees (“Gewaehrtraegerhaftung"). As savings banks compete with commercial banks for retail and commercial customers, commercial banks in Germany alleged that the government guarantees resulted in a significant competitive advantage for savings banks. Prompted by these allegations, the European Union filed a lawsuit against the government guarantees at the European Court of Justice in 2000. The subsequent decision on July 17, 2001 resulted in the removal of guarantees for savings banks and federal state banks in two steps. During a transition period from July 182001 to July 18 2005, newly contracted obligations (such as bonds or commercial paper) continued to be secured by government guarantees if their maturity is shorter than December 31 2015. In a second step, starting from July 18 2005, all newly contracted obligations were no longer covered. Obligations contracted before July 182001 are grandfathered. This implies that our sample largely covers the transition period between the full existence of the guarantees (until 2001) and their complete removal (2005). Hence, we check 
the extent to which the expectation of their complete removal affected bank behavior, and therefore, the borrower. The removal of the guarantees took place in 2001, in the middle of our observation period. One major advantage of our data set is that the removal was exogenously imposed by a court decision and thus creates a unique natural experiment. The period under consideration in this article, 1996-2006, was a period without major financial system turmoil in Germany and hence is particularly well suited to identify the effects of behavioral changes in response to changes in the safety net.

Specifically, we first measure the difference in outcomes between savings bank dependent firms and industries and firms and industries that are not savings bank dependent; this represents the first difference and is estimated separately for the period when public guarantees were in place and after their removal. Second, we measure the difference between the first difference estimated while the public guarantees were in place and after their removal; this represents the second difference. Further, given that our particular interest is the difference between how efficient versus inefficient firms react to the removal of guarantees, we examine the differences in differences separately for efficient and inefficient firms. Hence, the variation in the firms' efficiency represents a third difference in the firm-level analysis. We estimate different versions of regressions of the following form:

$Y_{i t}=\beta_{1}$ Guarante $_{t}+\beta_{2}\left(\right.$ Guarante $_{t} *$ Dependent $\left._{i}\right)+\theta^{\prime} X_{i t}+a_{i}+\varepsilon_{i t}$

We use a fixed effect estimator for equation (1). Guarantee $t_{t}$ is a dummy which equals one for the period when the public bank guarantees were still effective, i.e., 1995 until 2000, and is zero 
from 2001 to 2006 after the guarantees were removed. ${ }^{7}$

The dummy variable Dependent $_{i}$ is equal to one for observations that we classify as "dependent" on savings banks and zero otherwise (in the following: dependent and independent firms or sectors). Clearly, the way we define whether or not a firm or a sector is dependent is central for our analysis. In the firm-level analysis, for each borrower we calculate the average level of the share of loans from savings banks in total loans in the pre-2001 period. We use different definitions to ensure the robustness of our results, but in the baseline regressions we define Dependent $_{i}$, as follows: Borrowers that borrow exclusively from savings banks (a share of loans from savings banks in total loans of 100\%) are classified as savings bank dependent $\left(\right.$ Dependent $\left._{i},=1\right)$. Firms that obtain all of their loans from one savings bank (recall that regional separation applies and firms are only permitted to borrow from the savings bank in the town of their headquarter) would face substantial adverse selection problems in line with classic relationship lending models (Fama (1985), Sharpe (1990) and Detragiache, Garella and Guiso (2000)), when attempting to obtain a loan from a competitor bank. The reason is the informational advantage of the relationship bank over the competitor banks, which discourages the competitor banks to refinance the firm in case the relationship bank refuses to do so, because the competitor bank would anticipate financial distress at the refused firm. Therefore, we believe that for those firms, whom their relationship bank tightens the lending standards due to the removal of the guarantees, switching to a new bank will be difficult. Further, we classify a firm as independent $\left(\right.$ Dependent $\left._{i}=0\right)$, if the share of loans from savings banks is less than $10 \%$ of total loans. In the baseline setup, we omit all other firms with an intermediate level of savings bank dependency from the analysis. We examine the validity of this approach below.

\footnotetext{
${ }^{7}$ Note that the firm-level data that we use is extracted from year-end financial reports.
} 
Comparing the outcome variables before and after the removal of the guarantees may give us biased results, due to the possible time trends in our outcome variables. Hence we take the average amount of loans that each borrower receives from the savings banks as a ratio of its total loans in the pre-removal period to define Dependent ${ }_{i}$. We expect that for firms with such a low share of exposure to savings banks a change of screening or monitoring policies of savings banks to be unimportant as they may have ample access to funding from other non-savings banks. ${ }^{8}$

In the following we show that this measure is a persistent measure for each borrower. Moreover, to make sure that the two groups of dependent and independent borrowers are comparable, we match the two groups of borrowers on size so that we finally end up with two groups which are comparable in their observable characteristics but different in their dependence to the savings banks. As we will see, matching on size will result in a sample in which the borrowers are also comparable in other observable characteristics.

The variable of interest is the interaction term of Guarante $_{t}$ and Dependent $_{i}, \beta_{2}$ in (1), that provides the DD estimate of the effect of the guarantees on firms' behavior. Our model also includes a set of firm fixed effects, denoted by $a_{i}$ in (1). This enables us to control for all unobserved time-constant characteristics of the firms. A detailed description of all variables and the sources of data is provided in Table 1.

\footnotetext{
${ }^{8}$ The results are robust to the threshold on which we define savings banks independent borrowers. For example, the results remain unchanged if we change this threshold to any integer between $1 \%$ and $15 \%$. As an alternative specification, we use $S B D e p_{i}$ itself as a continuous treatment measure and we find the same results as in the main approach. Moreover, one could also measure savings banks dependence on the industry level. However, savings banks in Germany lend to firms from all types of industries. To check for this, we generate Table A1 which shows that the distributions of firms across industries in our sample and in the population of German firms are quite similar. Table A2 shows that the within-industry variation of savings banks dependence (on average a standard deviation of 0.36 ) is much larger than the between-industry variation of savings banks dependence. The latter accounts to 0.093 (industry means) respectably 0.145 (industry medians).
} 


\subsection{Firm-level Data}

We use a proprietary data set of savings banks' commercial borrowers from 1995 until 2006. ${ }^{9}$ Typical customers of savings banks are small and medium sized enterprises (SMEs). Such borrowers are particularly suited for answering our research question. These are all private firms, mainly dependent on bank loans and subject to strong informational asymmetries. At the same time SMEs, especially in the German economy, are a major driver of the total investments, employment and production. For example, according to statistics published by the German Federal Ministry of Economics and Technology, the German Mittelstand (SME sector) contributes almost $52 \%$ of the total economic output and accounts for about $37 \%$ of the overall turnover of German companies, which was about 2 trillion Euros in 2011. The SMEs in Germany also employ about $60 \%$ of all the employees subject to social security contributions.

To be able to compare the effect of the guarantees on the same borrowers, we keep only those firms that have at least one observation before and one observation after 2001 (the year in which guarantees were removed). All the variables are winsorized at the $1^{\text {st }}$ and $99^{\text {th }}$ percentiles. Next, we collapse the time series information into a pre- and post-2001 period to take care of possible time series correlations of the error terms as suggested in Bertrand, Duflo, and Mullainathan (2004) and Petersen (2009), and also to remove the spurious effects due to different numbers of appearances of firms in our sample. Finally, we drop financial firms to focus on the real sector of the economy. We also drop observations with leverage larger than 1.0. The final sample contains the data on 47,802 distinct borrowers.

Table 2 presents the summary statistics of the variables of interest in our sample of firm level

\footnotetext{
${ }^{9}$ Gropp, Gruendl, and Guettler (2014) use the same data set. They provide empirical evidence how the removal or public guarantees affect the savings banks' risk taking.
} 
data. On average, $69.3 \%$ of the borrowers' credits come from savings banks. This is as expected, as the pre-condition for appearing in the data set is that the firms have some sort of relationship with a savings bank. We nevertheless do have a sufficient number of firms that we are able to classify as savings bank independent: 5,618 or $11.75 \%$ of all firms in the data. The standard deviation of (0.349) also suggests sufficient variation to identify the effect. The average borrower is small and has 2.51 million euros worth of assets, invests 185 thousand euros per year, which is about $8.6 \%$ of its total assets. Its total sales are on average 3.4 million euros per year, and each year they grow with a rate of $4 \%$. Our sample is statistically quiet similar to the German population of firms in Amdeus dataset in the same period. Average German firm from Amadeus has assets of about 2.81 million Euros (2.51 in our sample). Moreover, the average German firm has about $46 \%$ debt ratio (47.4 in our sample). Average ROA in Amadeus sample is $7.1 \%$ (7.42 in our sample). Therefore, our sample is fairly representative of the German population of firms covered in the most comprehensive firm-level dataset.

To get a first glimpse of the data, we examine a number time series features of firm financing variables in the sample, both for savings banks dependent and savings banks independent firms. Figure 1 shows that firms in our sample finance more than $40 \%$ of their assets with bank debt. This share is stable during the years prior to the removal of the guarantees. In the period after 2001 this share tends to drop. Firms in our sample rely more on equity to compensate for the reduced bank debt. The equity ratio increases to above $20 \%$ in the years after 2003 which shows an increase of more than $30 \%$ in comparison to its average level in years prior to 2001 . In addition, the average firm uses trade credits of about $12 \%$ of their asset size, which is rather stable in our observation period. More interestingly, Figure 1 also shows that financing of savings banks dependent and independent borrowers look similar over time, except for the fact that 
savings banks dependent borrowers are in general also more bank dependent.

\subsection{Savings Bank Dependence and the Matched Sample}

The cross sectional part of our DD estimation relies on the assumption that SBDep is a persistent characteristic and is randomly assigned to the borrowers. We are concerned that our identification could be driven by transitory variations in the dependence of borrowers to savings banks. Theory would suggest that it is difficult for borrowers to switch banks. Sharpe (1990) for example considers a model of repeated corporate borrowing under adverse selection, in which lenders obtain inside information about their borrowers' quality. This inside information gives existing lenders an informational advantage over potential competitors at the refinancing stage and reduces ex-post competition. Therefore, this makes it difficult for the borrower to switch banks. Our results, presented in Figure 2, are in line with this argument. We follow an approach similar to Lemmon, Roberts, and Zender (2008) to examine the persistence of our measure of savings banks dependence. For each year we sort the borrowers in three groups based on their level of SBDep, put them in three portfolios and follow them through time. For example, we start by year 1995, generate the three portfolios based on the level of SBRatio, and follow the firms in each portfolio for the next 10 years of data that we have, and calculate the average SBRatio of each portfolio in each year. We then do the same with all the other years. Finally, we take the average

of the average SBRatio across event times. Event time is the distance to the year when the portfolio is generated, i.e., event time zero is the portfolio formation year. Panel A of Figure 2 presents the results. One can see that the borrowers which are savings banks dependent in the portfolio formation date remain savings banks dependent throughout the whole time span of our 
sample, and vice versa.

However, one could argue that the pattern that we see in Figure 2 may be simply capturing the cross sectional variation on other observables across our three portfolios. For example, we know that highly savings banks dependent firms are smaller. Therefore, it could be the case that we are just following three different size categories and not savings banks dependence levels. To address this issue we begin by running yearly cross sectional regressions of SBRatio on the observable characteristics that we think may be associated with the amount of borrowings from the savings banks, namely total and fixed asset size, employment, profitability and industry category. Then we take the residuals from these regressions (we denote it unexpected SBRatio) for each borrower in each year and perform the same sorting procedure that we did earlier for SBRatio itself. More specifically, each year we sort the borrowers into three groups based on the level of the unexpected SBRatio, and we follow them through time and calculate the average actual SBRatio for each portfolio. We go to the next year, sort the borrowers and follow them again. We do this procedure 12 times (from 1995 until 2006) and we end up with 12 sets of event time averages. Finally, for each portfolio, we take the average of average SBRatio across the event times and end up with three time series shown in Panel B of Figure 2. With this method we make sure that in each portfolio we have borrowers that are uncorrelated along the observable characteristics, i.e. we are now sure that none of the portfolios are dominated by big or small firms, for example. Two features of these figures make us believe that SBRatio is a persistent characteristics and exogenous to observable variables and therefore a valid variable to measure savings banks dependency. First, the sorting stays unchanged (the lines do not cross) over the course of twelve years. Second, there is a great amount of heterogeneity among the three portfolios and it does not disappear, even after controlling for observable characteristics. 
The second issue to address is to generate two otherwise comparable groups, one serving as the treatment group $($ Dependent $=1)$ and the other as the control $($ Dependent $=0)$. Panel A of Table 4 presents borrowers' characteristics for the two groups of savings banks dependent and independent borrowers before matching the borrowers on size. Looking at the average figures for firm characteristics, one immediately notices that size and savings banks dependence are negatively correlated. We also see that savings banks dependent borrowers are more profitable. To make sure that the two groups of dependent and independent borrowers are statistically similar on observables and that for every treatment borrower there is at least one comparable borrower from the control group, we match the borrowers on size. The results in Panel B of Table 4 show that matching on size in fact matches the borrowers on other dimensions too. The average value of the total and fixed assets, leverage and ROA of the two groups are very similar. ${ }^{10}$

\section{Firm-level Results}

In this section we present the results of the estimation of the differential treatment effects of the guarantees on firms' investment, rates of sales growth and technological efficiency. To show the effects of the guarantees on firms with different operational profitability records, we split the sample to four equal subsamples based on the firms' average pre-2001 ROA and run the same model as in equation (1) on these four samples separately.

\subsection{Investments}

Looking at Figure 3 one notices the sharp drop in investments ratio from the year 2000 to year 2001. As shown in Table 5, firms in our matched sample invest on average more than $11 \%$ of

\footnotetext{
${ }^{10}$ We also check for the distribution of the borrowers in the two groups across industries and we find that they are similarly distributed.
} 
their assets every year before 2000. However, this ratio drops to about $6 \%$ for savings bank dependent firms and to $8 \%$ for the independent firms after the removal of the guarantees.

As our unconditional differences-in-differences estimate in Panel A of Table 6 shows, the reduction in the firms' investment ratio is 4.8 percentage points for savings banks dependent borrowers while it is only 2.7 percentage points for those that are less dependent to savings banks. This unconditional DD estimate is significantly positive and suggests that in the presence of the guarantees savings banks dependent borrowers invest relatively more compared to savings banks independent firms.

Next we estimate the model presented in equation (1) and we add control variables and borrower fixed effects. We also use clustered standard errors at the industry-state level. ${ }^{11}$ Table 7 shows that the investments of the savings banks dependent borrowers are relatively high during the time when the guarantees are in place in comparison to less savings banks dependent borrowers. In particular, the investment ratio of the savings banks dependent borrowers is 2.12 percentage points higher than that of the independent borrowers when the guarantees are in place. This amounts to about 26,000 euro higher yearly investments for the average savings banks dependent borrower. Note that the average savings bank dependent borrower invests 94,560 euro per year. As a total across all of the 13,495 savings bank dependent firms, this effect amount to 351 million euro higher average yearly investments for the treated firms in our sample.

These effects are stronger for poorly performing borrowers. Columns 2 to 5 in Table 7 show that borrowers in the lower quartiles of the profitability distribution invest more than the other

\footnotetext{
${ }^{11}$ Autocorrelated error terms at the firm-period level are not an issue in our case, since we use the average values in the two periods of before and after the removal of the guarantees and not the yearly observations in the OLS estimations.
} 
borrowers in the presence of the guarantees. This implies that in the presence of the public guarantees, low performing borrowers maintain higher levels of investments than what they would do in the absence of the guarantees.

To see whether such differences are statistically significant, we run a triple interaction model, in which we use a dummy variable called LowROA which is equal to one for borrowers in the first quartile of average pre-2001 ROA distribution and zero otherwise. This variable helps us to differentiate the effects for worst performing borrowers in comparison to all other borrowers. Column 1 of Table A3 in the appendix shows that the coefficient on the triple interaction term is positive and statistically significant at the $1 \%$ level. All in all, our results in this section show that the guarantees help poorly performing borrowers to invest more than their better performing peers.

\subsection{Growth Rate of Sales}

After documenting that the guarantees lead to relatively higher investments for poorly performing borrowers, we next check whether such investments translate into higher sales. We construct a variable that measures the average yearly sales growth for each borrower in each period of before and after the removal of the guarantees. The evolution of this variable for the two groups of borrowers through time is presented in Figure 3. The average firm's sales grow at a rate between 6 and 9 percent for the savings bank dependent borrowers and between 3 and 7 percent for the independent borrowers, during 1995 until 2000. However, immediately after the removal of the guarantees this rate drops to $0 \%$ for the former group and to $2 \%$ for the latter. The rate of sales growth starts to recover again in 2005 and later. As it is seen in in the graph, the reduction in the sales growth is more pronounced for the savings bank dependent borrowers. In fact, Panel B of 
Table 6 presents the unconditional DD estimate of the effect of the guarantees on this variable. It shows that the savings banks dependent firms had 3.9 percentage points higher growth rate of sales in the presence of the guarantees in comparison to the firms which are independent from the savings banks.

We also run the fixed effects specification of equation (1). The results are presented in Table 8. We find that when the guarantees are in place, on average, savings banks dependent borrowers have 4.5 percentage points higher yearly rates of sales growth during the period when guarantees are effective. This is both statistically and economically significant. Average yearly sale equals to 1.71 million euros for the savings banks dependent borrowers in the pre-2001 period in our matched sample, and therefore 4.7 percentage points increase every year for each borrower amounts to more than 80,000 euro higher sales every year for the average firm, and 1085 million Euro in total for all savings banks borrowers in our sample.

Again, this effect is stronger for poorly performing borrowers, i.e., the ones with the lowest return on assets (column 2 of Table 8). Although we also see significant effect for highly profitable borrowers, the magnitude of this effect is $60 \%$ lower than that of the least profitable borrowers. Similar to the test for the investments ratio, we again include a triple interaction term to formally test for the statistical significance of this difference. Column 2 of Table A3 in the appendix shows results for which we compare the response of worst performing borrowers (those with pre-2001 ROA in the first quartile of its distribution) with all the other borrowers. We find that the coefficient on the triple interaction term is significantly positive. This implies that worst performing borrowers are able to keep higher sales growth rates than the other borrowers, when guarantees are in place. 


\subsection{Technical Efficiency}

So far we find that guarantees seem to help firms invest more and keep higher rates of sales growth. We next investigate firms' technological efficiency directly. Schumpeter (1942) emphasizes that growth arises from technologically efficient firms growing rapidly and driving technologically inefficient firms out of the market. If capital is allocated efficiently, one would expect firms that invest more to be more efficient as well. However, we find the opposite: When public guarantees are in place firms that are more dependent on savings banks invest more but are technically less efficient. This is direct evidence that public guarantees may have an adverse effect on growth through impairing allocative efficiency.

We estimate technical efficiency of the firms in our sample using a stochastic frontier approach as in Greene (2008). The approach is detailed in Appendix B. In short, we estimate an optimal production frontier using a Cobb-Douglas production function. The inverse of the distance of realized output of each firm to this frontier will be the measure of efficiency for that firm.

The summary statistics in Table 2 show that on average firms have a technical efficiency (TE) of $76.1 \%$ with a standard deviation of $14.2 \%$. The least efficient firm has a TE of only $3 \%$ and the most efficient one has a TE of 97.5\%. Panel C of Table 6 shows that savings banks dependent borrowers are less efficient than the firms less dependent to the savings banks. Both types of firms, however, have better efficiency measures in the period when the guarantees are removed, while savings bank dependent firms improved to a larger extent than savings bank independent firms (Figure 3). The unconditional DD estimate presented in Panel C of Table 6 shows that when the guarantees were in place the firms that were dependent on the savings banks were producing less efficiently relative to firms that were least dependent to savings banks. The fixed 
effects estimates in Table 9 also conform to this fact by showing a significant negative point estimate for the interaction term. Considering the finding that in the presence of guarantees firms invest more, these results imply that less investments have been spent on acquiring new technologies to facilitate improvements in the efficiency of production. Firms in the presence of the guarantees invest more and since the savings banks screening / monitoring may not be optimal, these investments are in part wasteful.

\section{Industry-level Firm Exits}

As we have seen so far in this paper, inefficient firms invest more and grow more rapidly in the presence of public guarantees. In this section, we examine the extensive margin: We estimate whether public guarantees have an effect on the rate at which firms exit the market. The exit of inefficient firms is a necessary condition for technological progress in the Schumpeter-type model of economic growth based on creative destruction. ${ }^{12}$

\subsection{Sectoral Data}

We use data from Germany's Federal Statistical Office (Destatis) to examine the effect of guarantees on firm exit. We gather the yearly number of firms in each industry that exit the market and the total number of firms in each sector. ${ }^{13}$ For the total number of firms in each sector we use value added tax (VAT) data from Germany's Federal Statistical Office. ${ }^{14}$ The data spans

\footnotetext{
${ }^{12} \mathrm{We}$ also examined firm birth rates and find that firm birth rates are lower in the presence of public guarantees. However, firm birth rates suffer from substantial measurement error in Germany, as we have to infer firm birth rates from data on the total number of firms and firm exits. These results are available from the authors upon request.

${ }^{13} \mathrm{We}$ assume the number of firms which pay taxes is a good proxy for the total number of operating firms in each industry-year cell.

${ }^{14}$ Companies with sales below 17,500 euro, companies with paid sales-taxes below 1,000 euro in the previous year and companies which do not pay sales taxes at all are not considered in this statistic.
} 
the years 1996 until 2006 and covers 13 industries. ${ }^{15}$ This is the highest level of disaggregation for firm exits that is available in Germany. In Table 3 we see the annual average number of total and exiting firms in each industry during the sample period.

We also gather the annual number of firms in each industry-state combination that file for bankruptcy. This is highly correlated with the actual number of exits on the industry level. ${ }^{16}$ The advantage of this data set, however, is that we have the number of firms that file for bankruptcy in each industry-state combination, which hence gives us more estimation power. This data, however, is available only for years from 1999 until 2006. It is available for 13 industries in 12 German states. ${ }^{17}$ Figure 4 depicts the total number of exits and filing for bankruptcies per year.

\subsection{Firm Exit}

We start by looking at the number of firms that leave the market each year (Exit), from 1996 until 2006. Figure 4 shows that there is an upward trend in the number of exiting firms starting in early 2000. This may or may not be due to the removal of public guarantees. In order to identify the effect of public guarantees, we follow a similar approach as in the previous section and investigate how this change in the number of exits differs for industries that are more dependent to savings banks in comparison to the less savings banks dependent industries.

Using the firm level data from Section 4, we define a measure of sectoral savings banks dependence during the period when the guarantees were effective. Specifically, we use the

\footnotetext{
${ }^{15}$ We drop the data from the finance industry, public administration and defence, private households and also extraterritorial organizations and bodies. The reason to do this is to focus only on the information related to the real business sector.

${ }^{16}$ The correlation coefficient is 0.92 even though bankruptcy is only one of many ways to exit; e.g., firms can also simply close and distribute the remaining assets among the owners or they may be taken over by another firm.

${ }^{17}$ As we did for the exit data, we drop the data regarding to the finance industry, public administration and defence, private households and also extraterritorial organizations and bodies.
} 
median firms' SBDep of each industry as an indicator of the savings banks dependence of that specific industry. This approach is also used in Bertrand, Schoar and Thesmar (2007). The last column of Table 3 shows the savings banks dependence of each industry.

We estimate the following regression to find the effect of the guarantees on the average number of firms that exit the market each year. For each industry, Dependent is equal to one if its SBDep is in the $4^{\text {th }}$ quartile of the distribution of SBDep and zero otherwise. This way we compare savings banks dependent industries with all the other industries.

$\log \left(\right.$ Exit $\left._{j t}\right)=\beta_{1}\left(\right.$ Guarante $_{t} \times$ Dependent $\left._{j}\right)+\beta_{2} \log _{\text {Total_\#_firms }}$ Tot $\left._{-}\right)+a_{t}+b_{j}+\varepsilon_{j t}$

The subscript $j$ rolls over the industries and $t$ over the years. We are interested in the estimate of $\beta_{1}$. The point estimate of this interaction term tells us by how much the number of exits differed between savings banks dependent industries when the guarantees were in place, in comparison to less savings banks dependent industries. We include year dummies $\left(a_{t}\right)$ and industry fixed effects $\left(b_{j}\right)$ in equation (2). Clustered standard errors are calculated at the industry-guarantee level, i.e., we allow for non-parametric autocorrelation of the error term in the two periods of before and after the removal of the guarantees for each industry.

The results are presented in Table 10. As it is presented in the first two columns, we find a negative and significant coefficient for the interaction term. This implies that when savings banks were still benefiting from the public guarantees, there were fewer firms leaving the market in savings banks dependent industries relative to less savings banks dependent industries. It is also economically significant since the highly savings banks dependent industries experienced around $28 \%$ fewer firms exiting the market when guarantees were effective relative to the less savings banks dependent industries. 


\subsection{Filing for Bankruptcy}

This section is devoted to analyzing the number of firms which file for bankruptcy each year. This includes the Exit measure above plus those filings for bankruptcies which are rejected due to the lack of assets to pay the cost of the insolvency proceedings. ${ }^{18}$ This can be seen as a robustness check for our results regarding the number of exits. Overall, this broader measure has a high correlation (0.92) with the actual number of firms which exit the market between 1999 and 2006. The advantage of this data set, however, is that we have the number of firms which file for bankruptcy in each industry-state combination for years from 1999 until 2006 . We have this information for 13 industries in 12 German states. Therefore, we are able to control for any time invariant unobservable characteristics among state-industry combinations.

We again use the median firm's SBDep in each industry-state as the measure of savings banks dependence of each particular industry-state combination. Similar to the previous section, we define an industry-state combination as highly savings banks dependent if its SBDep is in the fourth quartile of SBDep distribution. Dependent is equal to one if this is the case and zero otherwise. We estimate specifications that are similar to equation (2) but we use the logarithm of the number of bankruptcy filings as the dependent variable. We control for year and industrystate fixed effects. Finally, clustered standard errors are calculated at the industry-state-guarantee level.

The results are as presented in the last two columns of Table 10 . We find a yearly average of $32 \%$ less bankruptcy filings in the highly savings banks dependent sectors, in comparison to other sectors. These results are relatively close to what we estimated for the number of exits from the

\footnotetext{
${ }^{18}$ In the German bankruptcy law it is called "Abweisung mangels Masse".
} 
market. Altogether these results corroborate the hypothesis that public guarantees may prevent inefficient firms from exiting the market.

\section{Robustness Checks}

\subsection{Savings banks' ex ante reliance on publicly guaranteed debt}

If the miss-allocation of credit that we find in this study is caused by the public guarantees, we would expect this miss-allocation to be more pronounced where the guarantees are more prevalent. To test for this idea we follow a simple approach. In short, if a savings bank, ex ante, relies more on debt instruments which are guaranteed by the government, the capital misallocation on its borrowers should be higher. The reason is that other types of bank finances have not been altered around the year 2001. These banks still have deposit insurances. Moreover, regulations on capital adequacy ratios, especially Basel II, came after the period under study in our paper. Therefore, the only other major financing pillar for savings banks is all the other types of debt that banks had in their balance sheet. All such debt used to be guaranteed prior to 2001. Moreover, note that this type of financing is the most important mechanism through which market discipline could affect banks' behavior. With guarantees in place this mechanism was suppressed. Therefore, if a savings bank's pre-2001 reliance on guaranteed debt is high, we except to find higher capital distortion on the side of their borrowers. Here, we measure distortions by the coefficient of the triple interaction term in a difference-in-difference-indifferences model, where the third difference is between low performing borrowers and other borrowers (similar to what we did in Table A3).

In our dataset, for each firm we know the group of banks with which the firm has financial relationship and we also know all the banks in each group. Therefore, we do not see every single 
relationship, but rather the links between firms and groups of banks, which are geographically close to each other. There are 65 groups which in total comprise the universe of savings banks in Germany ${ }^{19}$. Therefore, we construct aggregate measure of equity ratio and deposit ratio for each bank group by using individual bank's data. Accordingly, we define ex-ante reliance on guaranteed debt as the pre-2001 average of 1 -deposit ratio - equity ratio. Next, we split the sample to four quartiles based on this measure and run our triple difference regressions for each sub-sample. The results are presented on Table A4 for investment ratio and on Table A5 for sales growth. As we see for both variables, the misallocation is bigger and more significant for the firms which are linked to banks with the highest ex-ante reliance on guaranteed debt.

\subsection{Propensity score matching}

Our baseline results are driven by applying fixed effect regressions on a matched sample. To make sure that our results are robust to the estimation method, we run a nearest neighbor propensity score matching estimation. First, for each borrower we calculate the change of the outcome variable from the non-guarantee period (post-2001) to the guarantee period (pre-2001). Then we compare this change for each savings banks dependent borrower versus that of a set of four nearest neighbors in terms of propensity scores. The propensity score is estimated by the means of a binary probit model where the covariates are total assets size, fixed assets and leverage plus categorical variables to control for the state and industry to which the borrower belongs. Finally, we report the analytical heteroskedasticity-consistent standard errors proposed in Abadie and Imbens (2006). The results are presented in Table 6. All the results point to the same conclusion as before. With the guarantees in place the worst performing borrowers invest more and have higher sales growth rates.

\footnotetext{
${ }^{19}$ Except for savings banks in Berlin and Hamburg.
} 


\subsection{Placebo treatment year}

As already seen in Figure 3, the variables of interest in our study have parallel trends before and after 2001, and the main effects that we capture in our regression results are driven by the more pronounced changes in each variable for the savings bank dependent group of borrowers at the time of the removal of guarantees. However, to make sure that these effects are solely due to the treatment (i.e., the removal of the guarantees) in 2001, we run a placebo test. Specifically, we assume that the treatment took place in 2004. Therefore, we define the period 2001 until 2003 as the pre-treatment period (Guarantees $=1$ ) and the period from 2004 until 2006 as the posttreatment period (Guarantees $=0$ ) and perform our main tests on this time period. The results of these tests are presented in Table A7 and Table A8. As one can see, none of the interaction terms are significant. First, as we see in Table A7, there is no difference between the two groups of the borrowers before and after 2004. Second, as in Table A8, the number of firms which exit the market are not statistically different in the two groups of savings bank dependent industries and savings bank independent industries before and after 2004. These results again point to the validity of the parallel trends assumption that the two groups perform similarly before and also after the treatment takes place, and it is only at the time of the treatment that the two groups differ in their response to it.

\subsection{Technical efficiency as a measure of firm quality}

We use the average pre-2001 technical efficiency of each borrower instead of its ROA to see whether our results are robust to the choice of ROA as a performance measure. In short, all of the results remain qualitatively unchanged. We find that the least efficient savings banks dependent 
borrowers invest more and keep higher sales growth rates relative to other borrowers in the presence of guarantees. The investments results are presented in Table A9 and the sales growth results in Table A10.

\subsection{Labor market reforms (Agenda 2010)}

Starting from 2003 German government pushed a series of labor market and welfare system reforms which now is known by the name Agenda 2010. The main targets of the reforms were to reduce the unemployment benefit duration, to make it easier for some parts of the economy to execute layoffs, to merge social security and unemployment welfare systems and finally to allow low income jobs to be combined with welfare benefits. Theoretically, these reforms should have reduced unemployment, and there is some evidence that they did (Burda and Hunt (2011)). There is no clear reason why Agenda 2010 should affect the savings banks dependent firms differently relative to firms less dependent to savings banks. However, to make sure that our results are not confounded by the following labor market reforms, we restrict our sample to years 2002 and earlier. We run our main regressions on this shortened sample and we find qualitatively unaffected results (see Appendix Table A11 to Table A13).

\section{Conclusion}

We study the effect of public bank guarantees on allocative efficiency, i.e. the ability of the financial system to efficiently allocate funding to its most productive use. Theory would predict that public guarantees for banks exacerbate moral hazard both for the banks (less incentives to screen and monitor borrowers) and their customers (more incentives to take on unproductive investments). The theory, hence, would imply that with public guarantees in place, less efficient firms are more likely and more efficient firms are less likely to obtain funding. Public guarantees 
reduce allocative efficiency. The consequences of this misallocation of funds may be lower growth in productivity and lower long-term growth.

The effect of public guarantees on long term economic outcomes is a particularly timely research question, since in the wake of the recent financial crisis, many governments extended public guarantees to banks. Moreover, the identification of the real effects of such interventions is tricky. We feel we are able to address these identification problems by using a natural experiment in Germany: long-standing public guarantees were removed for a set of German banks (but not all) following a lawsuit in 2001. This change in the legal setup happened in times of calm financial markets, helping us to isolate the effects of public guarantees.

Using matched bank/firm data we find that public guarantees reduce allocative efficiency. With guarantees in place poorly performing firms invest more and maintain higher rates of sales growth. Moreover, with the guarantees in place firms produce less efficiently. Consistently, we show that guarantees reduce firms' exit rates, a key ingredient of economic growth based on creative destruction thesis. These findings suggest that public guarantees hinder restructuring activities and prevent resources to flow to the most productive borrowers.

The results of the paper emphasize the need for a swift credible removal of the guarantees granted in the crisis, in order to avoid significant negative consequences for real growth. 


\section{References}

Abadie, A. and G. Imbens, 2006, Large Sample Properties of Matching Estimators for Average Treatment Effects", Econometrica 74(1), 235-267.

Banerjee, P., 2004, Information Acquisition Under Uncertainty in Credit Markets, Review of Financial Studies 18, 1075-1104.

Bertrand, M., A. Schoar, and D. Thesmar, 2007, Banking Deregulation and Industry Structure: Evidence from the French Banking Reforms of 1985, Journal of Finance 62, 597-628.

Bertrand, M., E. Duflo, and S. Mullainathan, 2004, How Much Should We Trust Differences-InDifferences Estimates?, The Quarterly Journal of Economics 119, 249-275.

Black, S. E., and P. E. Strahan, 2002, Entrepreneurship and Bank Credit Availability, The Journal of Finance 57, 2807-2833.

Boot, A. W. A., and S. I. Greenbaum, 1992, Bank Regulation, Reputation and Rents: Theory and policy implications. In: Colin Mayer and Xavier Vives (eds.) Capital Markets and Financial Intermediation, 262-285, Cambridge University Press.

Boyd, J. H., and M. Gertler, 1994, The Role of Large Banks in the Recent U.S. Banking Crisis, Federal Reserve Bank of Minneapolis, Quarterly Review 18.

Boyd, J. H., and D. E. Runkle, 1993, Size and Performance of Banking Firms: Testing the Predictions of Theory, Journal of Monetary Economics 31, 47-67.

Burda, M. C., and J. Hunt, 2011, What Explains the German Labor Market Miracle in the Great Recession?, Unpublished working paper.

Carletti E., V. Cerasi and S. Daltung, 2007, Multiple-bank lending: Diversification and freeriding in monitoring, Journal of Financial Intermediation 16-3, 425-451 
Cetorelli, N., and M. Gambera, 2001, Banking Market Structure, Financial Dependence and Growth: International Evidence from Industry Data, The Journal of Finance 56, 617-648.

Claessens, S., and L. Laeven, 2005, Financial Dependence, Banking Sector Competition, and Economic Growth, Journal of the European Economic Association 3, 179-207.

Corsetti, G., P. Pesenti, and N Roubini, 1999, Paper Tigers? A Model of the Asian Crisis, European Economic Review 43, 1211-1236.

Dell'Ariccia, G., E. Detragiache, and R. Rajan, 2008, The Real Effect of Banking Crises, Journal of Financial Intermediation 17, 89-112.

Detragiache, E., P. Garella, and L. Guiso, 2000, Multiple versus Single Banking Relationships: Theory and Evidence, The Journal of Finance 55, p 1133-1161.

Dewatripont, M., and E. Maskin, 1995, Credit and Efficiency in Centralized and Decentralized Economies, The Review of Economic Studies 62, p 541-555.

Dewatripont, M., J. Tirole, 1993, Efficient Governance Structure: Implications for Banking Regulation, in Colin Mayer, and Xavier Vives, eds.: Capital Markets and Financial Intermediation (Cambridge University Press, Cambridge).

Fama, Eugene F., 1985, What's different about banks?, Journal of Monetary Economics 15, 2939.

Fischer, M. J., C. Hainz, J. Rocholl, and S. Steffen, 2011, Government Guarantees and Bank Risk Taking Incentives, Unpublished working paper.

Freixas, Xavier, 1997, Microeconomics of banking (MIT Press, Cambridge, Mass).

Greene, W. H., 2008, The Econometric Approach to Efficiency Analysis, in H. O. Fried, K. Lovell, and S. S. Schmidt, eds.: The Measurement of Productive Efficiency and Productivity Change (Oxford University Press). 
Gropp, R., H. Hakenes, and I. Schnabel, 2011, Competition, Risk-shifting, and Public Bail-out Policies, Review of Financial Studies 24, 2084-2120.

Gropp, R., C. Gruendl, and A. Guettler, 2014, The Impact of Public Guarantees on Bank RiskTaking: Evidence from a Natural Experiment, Review of Finance 18, 457-488.

Hackethal, A., 2004, German Banks and Banking Structure, in J. P. Krahnen, and R. H. Schmidt, eds.: The German Financial System (Oxford University Press).

Hau, H., and M. P. Thum, 2009, Subprime Crisis and Board (in-) Competence: Private versus Public Banks in Germany, Economic Policy 24, 701-752.

Jayaratne, J., and P. E. Strahan, 1996, The Finance-Growth Nexus: Evidence from Bank Branch Deregulation, Quarterly Journal of Economics 111, 639-670.

Jensen, M. C., and W. H. Meckling, 1976, Theory of the Firm: Managerial Behavior, Agency Costs, and Ownership Structure, Journal of Financial Economics 3-4, 305-360

King, R. G., and R. Levine, 1993, Finance and Growth: Schumpeter Might be Right, The Quarterly Journal of Economics 108, 717-737.

Lemmon, M. L., M. R. Roberts, and J. F. Zender, 2008, Back to the Beginning: Persistence and the Cross-Section of Corporate Capital Structure, The Journal of Finance 63, 1575-1608.

Matutes, C., and X. Vives, 1995, Imperfect competition, risk taking, and regulation in banking, European Economic Review 44-1, 1-34.

Peek, J., and E. S. Rosengren, 2000, Collateral Damage: Effects of the Japanese Bank Crisis on Real Activity in the United States, American Economic Review 90, 30-45.

Petersen, M. A., 2008, Estimating Standard Errors in Finance Panel Data Sets: Comparing Approaches, Review of Financial Studies 22, 435-480. 
Puri, M., J. Rocholl, and S. Steffen, 2011, Global Retail Lending in the Aftermath of the US Financial Crisis: Distinguishing between Supply and Demand Effects, Journal of Financial Economics 100, 556-578.

Rajan, R. G., and L. Zingales, 1998, Financial Dependence and Growth, American Economic Review 88, 559-586.

Sapienza, P., 2004, The Effects of Government Ownership on Bank Lending, Journal of Financial Economics 72, 357-384.

Schnabel, I., and T. Körner, 2012, Abolishing Public Guarantees in the Absence of Market Discipline, Unpublished working paper.

Schumpeter, J. A., 1942, Capitalism, Socialism, and Democracy (Routledge, London, New York).

Sharpe, S. A., 1990, Asymmetric Information, Bank Lending, and Implicit Contracts: A Stylized Model of Customer Relationships, Journal of Finance 45, 1069-1087. 


\section{Figure 1 - Capital Structure}

The data are on the firm-by-year level. All the variables are defined as in Table 1.
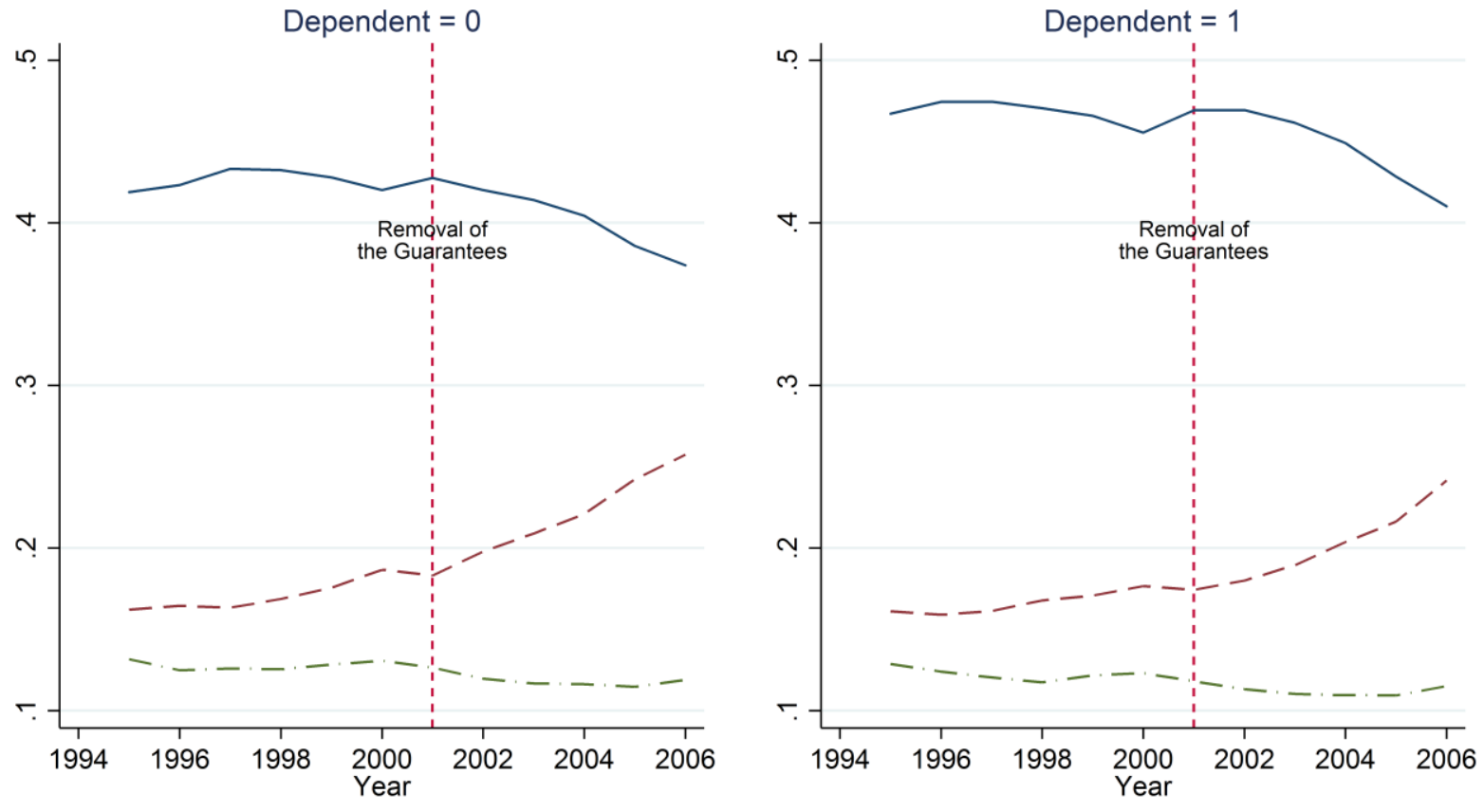


\section{Figure 2 - Persistence of Savings Banks Dependence}

Low denotes to the portfolio of firms in the first tercile of the SBRatio distribution in each event time period. Medium denotes to the firms in the second tercile and High to the third tercile of SBRatio in each event time. SBRatio is defined as the firm's loans from savings banks divided by its total loans from banks. Unexpected SBRatio is the unobservable part of the firms' SBRatio and is defined as the residual of a regression of SBRatio on total and fixed assets, employment, profitability and industry dummies.
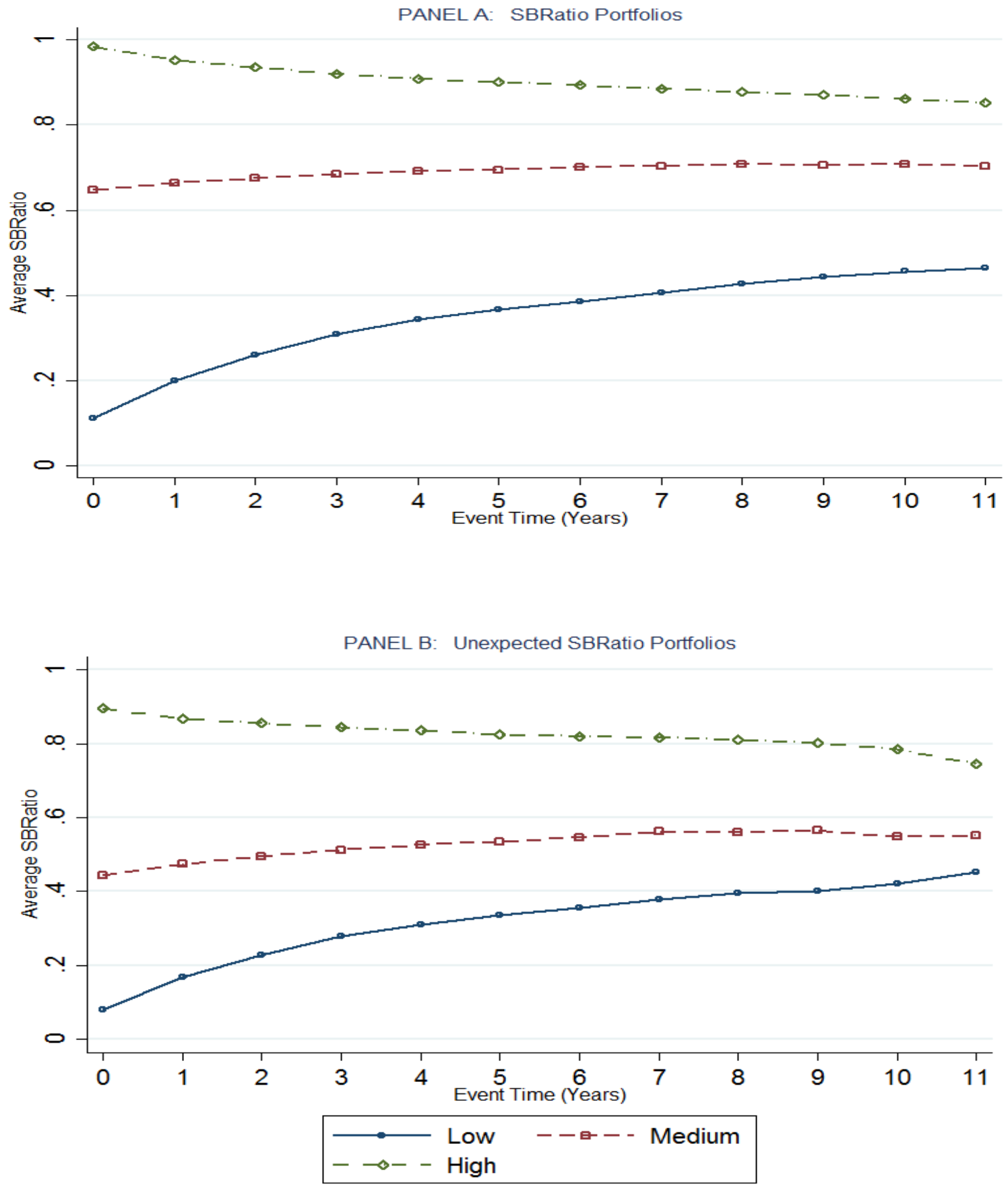


\section{Figure 3 - Parallel Trends}

The data are on the firm-by-year level from the final matched sample. All the variables are defined as in Table 1. The dummy variable Dependent takes the value 1 for savings bank dependent firms, as defined in the text.
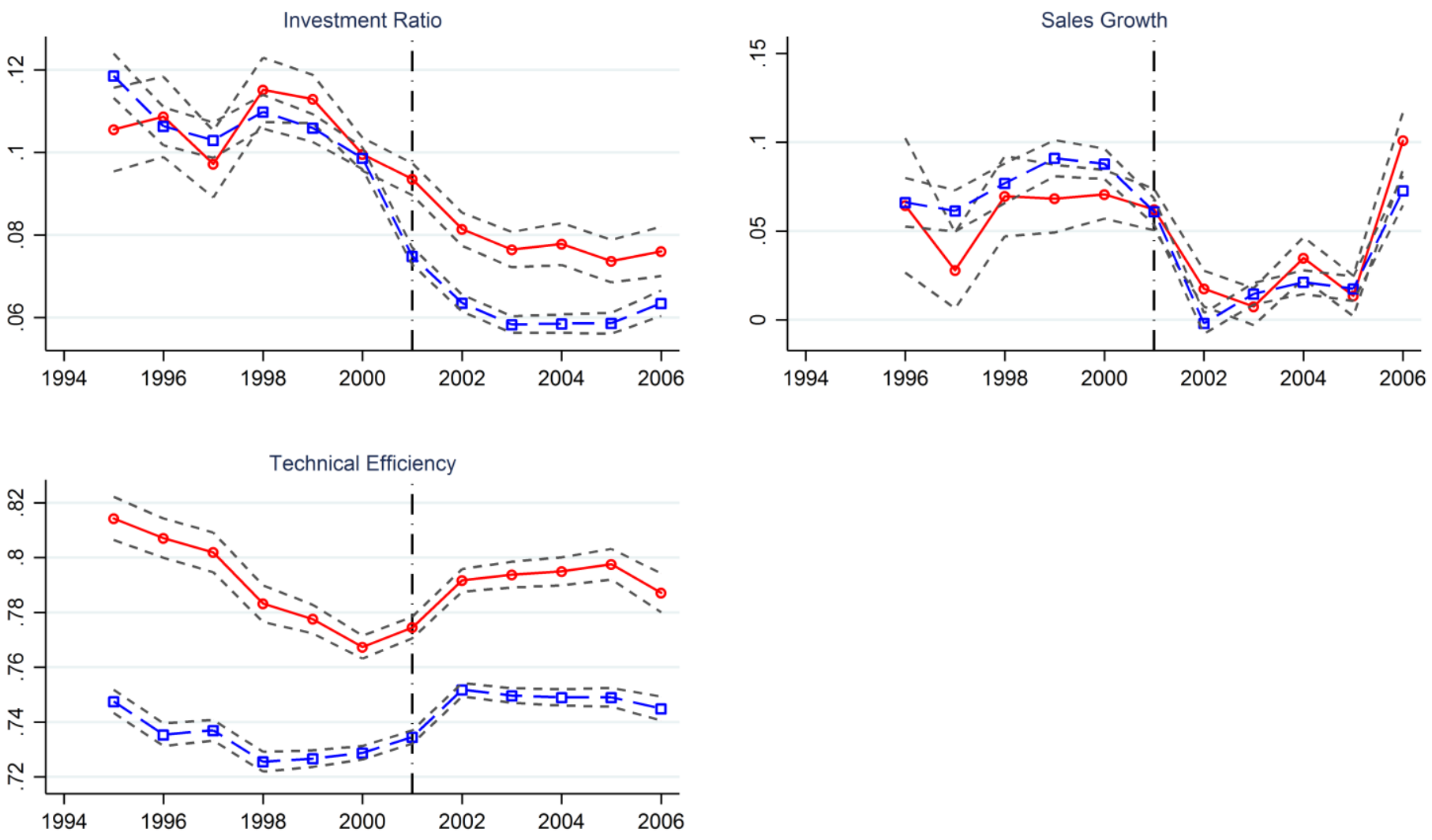

$$
\text { - Dependent }=0 \quad \text { - } 0 \text { Dependent }=1
$$


Figure 4 - Total Number of Exits and Bankruptcy filings

Exit is the actual number of firms that go bankrupt. File for Bankruptcy is the number of firms that file for bankruptcy each year. Note that the files for bankruptcy begin in 1999.

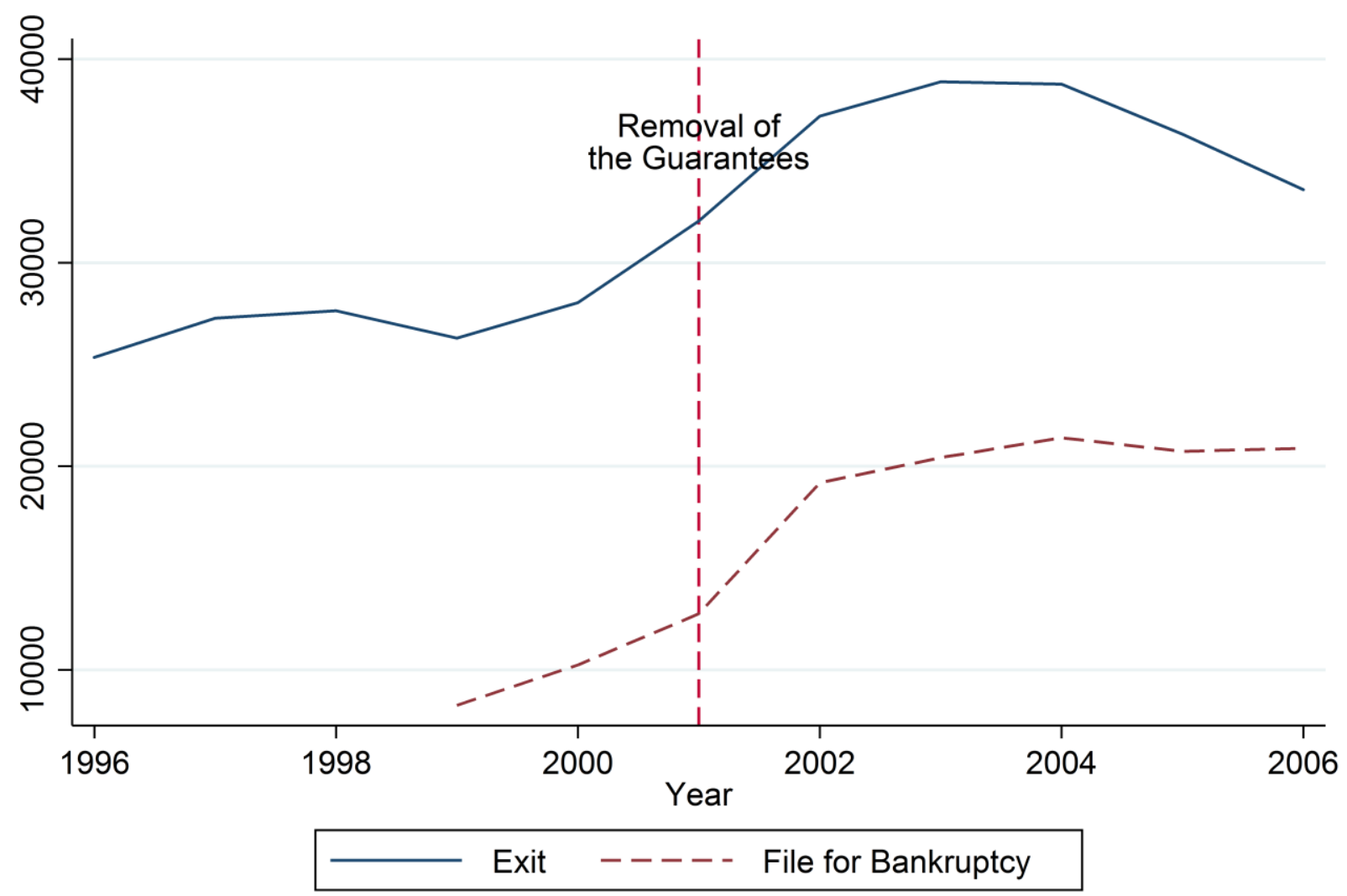


Table 1 - Data sets and Variable Definitions

\begin{tabular}{|c|c|c|}
\hline Data set & Variable & Definition \\
\hline \multirow{12}{*}{$\begin{array}{l}\text { Savings banks' borrowers' data set. } \\
\text { Savings banks' borrowers report their } \\
\text { balance-sheet and income statement to } \\
\text { the Savings Banks Association every } \\
\text { year. We use this data set to generate a } \\
\text { sample of borrowers with different } \\
\text { levels of dependence to the savings } \\
\text { banks. }\end{array}$} & Assets & Total assets measured in 1995 million euros \\
\hline & SBRatio & $\begin{array}{l}\text { Loans borrowed from savings banks divided by total loans. This variable is calculated } \\
\text { for each borrower-year observation and then averaged for two periods of before and } \\
\text { after the removal of the guarantees }\end{array}$ \\
\hline & SBDep & Average SBRatio in the pre-2001 period. Therefore it is time-constant. \\
\hline & Dependent & $\begin{array}{l}\text { A dummy variable which is equal to one for borrowers with } S B D e p=1 \text { and zero for } \\
\text { firms with } S B D e p<=0.1\end{array}$ \\
\hline & Investments Ratio & Total investments divided by total assets. \\
\hline & Sales growth & Yearly growth rate of sales. \\
\hline & Leverage & Total liabilities divided by total assets. \\
\hline & Bank debt & Total loans from banks divided by total assets. \\
\hline & Equity & Total equity divided by total assets. \\
\hline & ROA & Net income divided by total assets. \\
\hline & Trade credit & Trade payables divided by total assets. \\
\hline & Tech. Efficiency & Estimated technical efficiency using a stochastic production frontier method. \\
\hline \multirow{4}{*}{$\begin{array}{l}\text { Destatis (Germany's Federal Statistical } \\
\text { Office) collects, among other things, the } \\
\text { total number of firms operating, entering } \\
\text { or exiting the market. }\end{array}$} & Exit & $\begin{array}{l}\text { Yearly total number of firms which go out of the market in each industry throughout } \\
\text { Germany. }\end{array}$ \\
\hline & Exit Rate & Total number of exits as a share of total number of firms for each sector. \\
\hline & File for Bankruptcy & $\begin{array}{l}\text { Yearly total number of firms which file for bankruptcy in each industry-state in } \\
\text { Germany. }\end{array}$ \\
\hline & Total Firms & Total number of operating firms in each state, industry or state-industry. \\
\hline
\end{tabular}




\section{Table 2 - Summary Statistics of the Firm-level Data}

For every variable, we only consider observations of those borrowers, which appear in our sample both before and after the reform. $S B$ Ratio is the ratio of loans from savings banks to total loans for each borrower. Assets, Investments and Sales are measured in 1995 million euros. Investments Ratio is investments per euro of assets. Sales Growth Rate is yearly average of sales growth. Leverage is total liabilities divided by total assets. Bank Debt is firm's total loans from banks divided by total assets. ROA is net profit divided by total assets. Trade Credit Ratio is equal to trade payables divided by total assets. Technical Efficiency (TE) is the estimated technical efficiency of firms using a stochastic production frontier approach.

\begin{tabular}{|c|c|c|c|c|c|c|c|c|}
\hline & $\mathrm{N}$ & Mean & Std. dev. & Min. & p25 & $\mathrm{p} 50$ & p75 & Max. \\
\hline SB Ratio & 95,604 & 0.6930 & 0.3490 & 0.0000 & 0.4240 & 0.8560 & 1.0000 & 1.0000 \\
\hline Assets & 95,604 & 2.5100 & 6.0600 & 0.0392 & 0.3060 & 0.6860 & 1.8400 & 45.3000 \\
\hline Leverage & 95,604 & 0.7670 & 0.2130 & 0.1200 & 0.6400 & 0.8260 & 0.9460 & 1.0000 \\
\hline Bank Debt & 95,604 & 0.4740 & 0.2570 & 0.0085 & 0.2620 & 0.4700 & 0.6810 & 0.9950 \\
\hline Equity Ratio & 95,604 & 0.1610 & 0.1870 & -0.4510 & 0.0126 & 0.0943 & 0.2470 & 0.8380 \\
\hline Trade Credit Ratio & 89,883 & 0.1210 & 0.1200 & 0.0000 & 0.0347 & 0.0830 & 0.1660 & 0.6280 \\
\hline Investments & 95,604 & 0.1850 & 0.4960 & 0.0000 & 0.0078 & 0.0317 & 0.1240 & 3.9200 \\
\hline Investments Ratio & 95,604 & 0.0864 & 0.1090 & 0.0000 & 0.0150 & 0.0474 & 0.1150 & 0.6890 \\
\hline Sales & 95,604 & 3.4000 & 7.8000 & 0.0180 & 0.3670 & 0.9170 & 2.6200 & 55.7000 \\
\hline Sales Growth & 75,122 & 0.0398 & 0.2440 & -0.6230 & -0.0584 & 0.0025 & 0.0814 & 1.9800 \\
\hline ROA & 95,604 & 0.0742 & 0.1580 & -0.3250 & 0.0000 & 0.0327 & 0.1030 & 0.9600 \\
\hline Technical Efficiency (TE) & 90,048 & 0.7610 & 0.1420 & 0.0302 & 0.6820 & 0.7890 & 0.8680 & 0.9750 \\
\hline
\end{tabular}


Table 3- The Distribution of Exit, Total Firms, Exit rate and SBDep across Industries

The sample is generated from the Destatis database. Exit denotes the number of firms which go bankrupt in each industry. Total Firms is the number of operating firms in each industry. Entry is calculated as the difference between total number of firms in two consecutive years and the number of firms which go bankrupt. SBDep is the median firm's SBDep in each industry.

\begin{tabular}{lcccc}
\hline \multirow{2}{*}{\multicolumn{1}{c}{ Industry }} & \multicolumn{3}{c}{ Yearly Average Number of } & \multirow{2}{*}{ SBDep } \\
\cline { 2 - 4 } & Exit & Total Firms & Exit Rate & \\
\hline Agriculture, Hunting and Forestry & 544 & 68,077 & 0.0080 & 0.833 \\
Fishing & 5 & 782 & 0.0065 & 0.903 \\
Mining & 26 & 2,607 & 0.0108 & 0.702 \\
Manufacturing & 3,654 & 285,997 & 0.0128 & 0.839 \\
Electricity, Gas and Water Supply & 21 & 11,787 & 0.0018 & 0.790 \\
Construction & 8,049 & 318,226 & 0.0253 & 0.811 \\
Whole sale and Retail & 6,674 & 719,358 & 0.0093 & 0.858 \\
Hotel and Restaurants & 2,418 & 250,799 & 0.0097 & 0.970 \\
Transport, Storage and Communication & 2,021 & 126,610 & 0.0160 & 0.673 \\
Real Estate & 6,578 & 762,601 & 0.0085 & 0.824 \\
Education & 162 & 27,025 & 0.0059 & 0.858 \\
Health and Social Work & 441 & 38,120 & 0.0111 & 0.913 \\
Personal Service Activities & 1,351 & 272,956 & 0.0048 & 0.913 \\
\hline
\end{tabular}




\section{Table 4- Descriptive Statistics for the Un-matched and the Matched Samples}

For every variable we only consider observations of those borrowers which appear in our sample both before and after the removal of the guarantees. Dependent equal to one refers to the borrowers with SBDep equal to one. Dependent equal zero refers to the borrowers with SBDep less than 10 percent. Total Assets and Fixed Assets are measured in 1995 million euros. Leverage is total liabilities divided by total assets. ROA is net profit divided by total assets. Z-Score measures the distance to default and is measured using a modified Altman Z-score for the German economy. Panel A presents the summary statistics of the variables for the two groups of savings banks related and savings banks unrelated borrowers before matching on assets. Panel B presents the same statistics for the two samples after we run our matching procedure on assets.

\begin{tabular}{clccccc}
\hline Panel A: Before Matching & $\begin{array}{c}\text { \# of Distinct } \\
\text { Borrowers }\end{array}$ & $\begin{array}{c}\text { Total } \\
\text { Assets }\end{array}$ & $\begin{array}{c}\text { Fixed } \\
\text { Assets }\end{array}$ & Leverage & ROA \\
\hline Before & Dependent $=0$ & 5,618 & 5.674 & 2.116 & 0.729 & 0.063 \\
2001 & Dependent $=1$ & 13,495 & 1.092 & 0.440 & 0.748 & 0.105 \\
After & Dependent $=0$ & 5,618 & 5.853 & 2.172 & 0.710 & 0.057 \\
2001 & Dependent $=1$ & 13,495 & 1.159 & 0.456 & 0.730 & 0.104 \\
\hline
\end{tabular}

Panel B: After Matching

\begin{tabular}{ccccccc}
\hline Before & Dependent $=0$ & 4,128 & 1.228 & 0.432 & 0.748 & 0.076 \\
2001 & Dependent $=1$ & 12,005 & 1.218 & 0.492 & 0.747 & 0.077 \\
After & Dependent $=0$ & 4,128 & 1.370 & 0.482 & 0.730 & 0.070 \\
2001 & Dependent $=1$ & 12,005 & 1.288 & 0.508 & 0.725 & 0.079 \\
\hline
\end{tabular}




\section{Table 5 - Summary Statistics of the Variables of Interest in the Matched Sample}

The sample includes only the 16133 matched borrowers. The table compares time series change in the main firm-level outcome variables. All the variables are defined as in Table 1.

\begin{tabular}{lccccc}
\hline \multirow{2}{*}{ Variables } & \multicolumn{2}{c}{ Before 2001 } & & \multicolumn{2}{c}{ After 2001 } \\
\cline { 2 - 3 } \cline { 5 - 6 } & Mean & Std. Dev. & & Mean & Std. Dev. \\
\hline Investment Ratio & 0.1101 & 0.14 & & 0.0675 & 0.09 \\
Sales Growth & 0.0960 & 0.33 & & 0.0305 & 0.25 \\
Tech. Efficiency & 0.7395 & 0.13 & & 0.7510 & 0.13 \\
\hline
\end{tabular}




\section{Table 6 - Unconditional DD Estimations}

The table shows the unconditional differences-in-differences (DD) estimations. Guaranteed denotes to the period from 1995 until 2000 and Not guaranteed denotes to the years from 2001 until 2006. All the variables are defined as in Table 1.*,**, and *** denote significance at the 10,5 , and 1 percent level, respectively.

\begin{tabular}{lcccc}
\hline \multicolumn{5}{c}{ Panel A: Investments Ratio } \\
\hline & Dependent $=0$ & Dependent $=1$ & Difference & DD \\
\hline (1) Guaranteed & 0.1068 & 0.1112 & 0.0044 & \multirow{2}{*}{$0.0212^{* * *}$} \\
(2) Not guaranteed & 0.0799 & 0.0632 & -0.0168 & \\
\hline$(1)-(2)$ & 0.0268 & 0.0480 & & \\
\hline
\end{tabular}

Panel B: Sales Growth

\begin{tabular}{lcccc}
\hline & Dependent $=0$ & Dependent $=1$ & Difference & DD \\
\hline (1) Guaranteed & 0.0726 & 0.1024 & 0.0298 & \multirow{2}{*}{$0.0389 * * *$} \\
(2) Not guaranteed & 0.0372 & 0.0282 & -0.0091 & \\
\hline$(1)-(2)$ & 0.0354 & 0.0743 & & \\
\hline
\end{tabular}

Panel C: Technical Efficiency

\begin{tabular}{lcccc}
\hline & Dependent $=0$ & Dependent $=1$ & Difference & DD \\
\hline (1) Guaranteed & 0.7698 & 0.7289 & -0.0409 & \multirow{2}{*}{-0.0002} \\
(2) Not guaranteed & 0.7810 & 0.7403 & -0.0407 & \\
\hline$(1)-(2)$ & -0.0112 & -0.0114 & & \\
\hline
\end{tabular}




\section{Table 7 - Investments Ratio}

The sample is the two period borrower level matched panel. Investments Ratio is investments per euro of total assets. Guarantee is a dummy equal to one for years 1995 until 2000 and zero for years 2001 until 2006. Dependent is a dummy equal to one for borrowers with SBDep equal to one and is zero for borrowers with SBDep less than 10 percent. All the regressions include firm fixed effects. The standard errors in parentheses are corrected for clustering at the industrystate level. *, **, and *** denote significance at the 10, 5, and 1 percent level, respectively.

\begin{tabular}{lccccc}
\hline & Full Sample & \multicolumn{3}{c}{ Pre-2001 ROA Quartiles } \\
\cline { 3 - 6 } Investment Ratio & & 1 st & 2nd & 3rd & 4th \\
\hline Guarantee & $0.0268^{* * *}$ & $0.0308^{*} * *$ & $0.0239 * * *$ & $0.0253 * * *$ & $0.0284 * * *$ \\
GuaranteexDependent & $(0.002)$ & $(0.004)$ & $(0.004)$ & $(0.003)$ & $(0.006)$ \\
& $\left(0.0212^{* * *}\right.$ & $0.0348^{* * *}$ & $0.0179 * * *$ & $0.0150^{* * *}$ & $0.0152^{* * *}$ \\
& & $(0.006)$ & $(0.005)$ & $(0.004)$ & $(0.006)$ \\
Firm controls & Yes & Yes & Yes & Yes & Yes \\
Firm FE & Yes & Yes & Yes & Yes & Yes \\
Adj. R-squared & 0.088 & 0.125 & 0.078 & 0.077 & 0.073 \\
Number of Obs. & 32266 & 8144 & 7990 & 8066 & 8066 \\
\hline
\end{tabular}




\section{Table 8 - Sales Growth}

The sample is the two period borrower level matched panel. Sales Growth is yearly average rate of sales growth. Guarantee is a dummy equal to one for years 1995 until 2000 and zero for years 2001 until 2006. Dependent is a dummy equal to one for borrowers with SBDep equal to one and is zero for borrowers with SBDep less than 10 percent. All the regressions include firm fixed effects. The standard errors in parentheses are corrected for clustering at the industrystate level. *,**, and $* * *$ denote significance at the 10,5 , and 1 percent level, respectively.

\begin{tabular}{lccccc}
\hline & \multirow{2}{*}{ Full Sample } & \multicolumn{4}{c}{ Pre-2001 ROA Quartiles } \\
\cline { 3 - 6 } Sales Growth & & 1st & 2nd & 3rd & 4th \\
\hline Guarantee & $0.0485^{* * *}$ & 0.0354 & $0.0501^{* * *}$ & $0.0596^{* * *}$ & $0.0477^{* * *}$ \\
GuaranteexDependent & $(0.007)$ & $(0.023)$ & $(0.013)$ & $(0.017)$ & $(0.018)$ \\
& $0.0447^{* * *}$ & $0.0878^{* * *}$ & $0.0518^{* * *}$ & 0.007 & $0.0349^{*}$ \\
& $(0.009)$ & $(0.026)$ & $(0.017)$ & $(0.017)$ & $(0.021)$ \\
Firm controls & & & & & \\
Firm FE & Yes & Yes & Yes & Yes & Yes \\
Adj. R-squared & Yes & Yes & Yes & Yes & Yes \\
Number of Obs. & 0.049 & 0.052 & 0.056 & 0.036 & 0.065 \\
\hline
\end{tabular}




\section{Table 9 - Technical Efficiency}

The sample is the two period borrower level matched panel. Technical efficiency is estimated using a stochastic production frontier approach. Guarantee is a dummy equal to one for years 1995 until 2000 and zero for years 2001 until 2006. Dependent is a dummy equal to one for borrowers with SBDep equal to one and is zero for borrowers with SBDep less than 10 percent. All the regressions include firm fixed effects. The standard errors in parentheses are corrected for clustering at the industry-state level. *,**, and *** denote significance at the 10,5 , and 1 percent level, respectively.

\begin{tabular}{lc}
\hline & Full Sample \\
\hline Technical Efficiency & $-0.0061^{* * *}$ \\
& $(0.001)$ \\
GuaranteexDependent & $-0.0036^{* * *}$ \\
& $(0.001)$ \\
Firm controls & \\
Firm FE & Yes \\
Adj. R-squared & Yes \\
Number of Obs. & 0.425 \\
\hline
\end{tabular}




\section{Table 10 - The Effect of Public Guarantees on Exit and Bankruptcy Filings}

The sample is the yearly industry level data on Exit. Dependent is a dummy which is equal to one for industries that are in the highest quartile of SBDep distribution and is zero for the others. Guarantee is a dummy equal to one for years between 1996 and 2000 and zero otherwise. Standard errors, shown in parenthesis, are clustered at the sector-by-guarantee level. $*, * *$, and $* * *$ denote significance at the 10,5 , and 1 percent level, respectively.

\begin{tabular}{lcccc}
\hline & $\log ($ Exit $)$ & $\log ($ Exit $)$ & $\log (\mathrm{BF})$ & $\log (\mathrm{BF})$ \\
\hline GuaranteexDependent & $-0.367 * * *$ & $-0.280 * * *$ & $-0.313 * * *$ & $-0.321 * * *$ \\
& $(0.095)$ & $(0.060)$ & $(0.092)$ & $(0.093)$ \\
Log(Total No. Firms) & & $0.762 * * *$ & & $0.604 * *$ \\
& & $(0.215)$ & & $(0.240)$ \\
Sector FE & Yes & Yes & Yes & Yes \\
Year FE & Yes & Yes & Yes & Yes \\
Adj. R-squared & 0.986 & 0.989 & 0.522 & 0.529 \\
Number of Obs. & 143 & 143 & 1037 & 1037 \\
\hline
\end{tabular}




\section{Appendix A}

\section{Table A1 - Sample and Population Distribution of Industries}

Sample distribution shows the percentage of firms in our sample which belong to each industry during 1995 until 2006. Population distribution shows the distribution of firms in Germany's economy in the same period.

\begin{tabular}{lcc}
\hline Industry & Sample Distribution & Population Distribution \\
\hline Agriculture, hunting, forestry, fishing & 2.860 & 2.487 \\
Construction & 14.698 & 11.100 \\
Education & 0.199 & 0.960 \\
Electric, Gas and Water Supply & 0.093 & 0.477 \\
Health and Social Work & 1.589 & 1.394 \\
Hotels and Restaurants & 4.490 & 8.593 \\
Manuf. Chemicals, Petroleum and Coke & 0.333 & 0.174 \\
Manuf. Electronic Products & 1.949 & 1.180 \\
Manuf. Food, beverage and Tobacco & 2.946 & 0.711 \\
Manuf. Leather \& Miscellaneous & 1.283 & 0.916 \\
Manuf. Machinery & 1.818 & 0.856 \\
Manuf. Metal Products & 3.934 & 1.846 \\
Manuf. Non-metallic Minerals & 0.993 & 0.491 \\
Manuf. Paper & 1.439 & 1.005 \\
Manuf. Rubber and Plastic & 1.056 & 0.285 \\
Manuf. Textile & 0.499 & 0.424 \\
Manuf. Transport Equipment & 0.408 & 0.195 \\
Manuf. Wood & 1.509 & 0.683 \\
Mining & 0.156 & 0.050 \\
Other Services & 2.448 & 9.779 \\
Public Administration & 0.018 & 0.012 \\
Real Estate & 10.872 & 27.283 \\
Retail & 9.632 & 14.613 \\
Transport, Storage and Communication & 3.717 & 4.305 \\
Wholesale & 12.565 & 10.182 \\
\hline & & \\
\hline
\end{tabular}


Table A2 - The Distribution of Savings Bank Dependency across Industries

The total number of firms is 47,802 . For each industry we compute the mean and median level of SBDep. The last column shows the within-industry standard deviation of SBDep. The last row provides the between-industry standard deviation of the mean and median SBDep.

\begin{tabular}{|c|c|c|c|c|c|}
\hline \multicolumn{2}{|r|}{ Industry } & \multirow{2}{*}{$\begin{array}{c}\mathrm{N} \\
1,262\end{array}$} & \multirow{2}{*}{$\begin{array}{l}\text { Mean } \\
0.677\end{array}$} & \multirow{2}{*}{$\begin{array}{c}\text { Median } \\
0.825\end{array}$} & \multirow{2}{*}{$\begin{array}{c}\text { Within- } \\
\text { industry } \\
\text { Std. dev. } \\
0.345\end{array}$} \\
\hline 1 & Agriculture, hunting, forestry, fishing & & & & \\
\hline 2 & Construction & 6,485 & 0.684 & 0.811 & 0.335 \\
\hline 3 & Education & 88 & 0.691 & 0.834 & 0.358 \\
\hline 4 & Electric, Gas and Water Supply & 41 & 0.562 & 0.859 & 0.469 \\
\hline 5 & Health and Social Work & 701 & 0.660 & 0.852 & 0.382 \\
\hline 6 & Hotels and Restaurants & 1,981 & 0.838 & 0.979 & 0.272 \\
\hline 7 & Manuf. Chemicals, Petroleum and Coke & 147 & 0.627 & 0.764 & 0.387 \\
\hline 8 & Manuf. Electronic Products & 860 & 0.691 & 0.876 & 0.358 \\
\hline 9 & Manuf. Food, beverage and Tobacco & 1,300 & 0.723 & 0.886 & 0.333 \\
\hline 10 & Manuf. Leather \& Miscellaneous & 566 & 0.670 & 0.822 & 0.353 \\
\hline 11 & Manuf. Machinery & 802 & 0.635 & 0.797 & 0.378 \\
\hline 12 & Manuf. Metal Products & 1,736 & 0.686 & 0.851 & 0.352 \\
\hline 13 & Manuf. Non-metallic Minerals & 438 & 0.655 & 0.784 & 0.354 \\
\hline 14 & Manuf. Paper & 635 & 0.629 & 0.752 & 0.373 \\
\hline 15 & Manuf. Rubber and Plastic & 466 & 0.614 & 0.747 & 0.380 \\
\hline 16 & Manuf. Textile & 220 & 0.621 & 0.742 & 0.377 \\
\hline 17 & Manuf. Transport Equipment & 180 & 0.605 & 0.752 & 0.391 \\
\hline 18 & Manuf. Wood & 666 & 0.703 & 0.857 & 0.339 \\
\hline 19 & Mining & 69 & 0.618 & 0.730 & 0.369 \\
\hline 20 & Missing Industry & 8,161 & 0.695 & 0.878 & 0.359 \\
\hline 21 & Other Services & 1,080 & 0.731 & 0.920 & 0.340 \\
\hline 22 & Private Households & 3,679 & 0.669 & 0.831 & 0.364 \\
\hline 23 & Public Administration & 8 & 0.279 & 0.160 & 0.345 \\
\hline 24 & Real Estate & 4,797 & 0.656 & 0.835 & 0.380 \\
\hline 25 & Retail & 4,250 & 0.762 & 0.931 & 0.318 \\
\hline 26 & Transport, Storage and Communication & 1,640 & 0.603 & 0.652 & 0.348 \\
\hline 27 & Wholesale & 5,544 & 0.646 & 0.771 & 0.357 \\
\hline & Between-industry Std. dev. & & 0.093 & 0.145 & \\
\hline
\end{tabular}




\section{Table A3 - Differential Effects across ROA for the Firm-level Analysis}

The sample is the two period borrower level matched panel. Investments Ratio is investments per euro of total assets. Sales Growth is the yearly average rate of sales growth. Guarantee is a dummy equal to one for years 1995 until 2000 and zero for years 2001 until 2006. Dependent is a dummy equal to one for borrowers with $S B D e p$ equal to one and is zero for borrowers with SBDep less than 10 percent. LowROA is a dummy equal to one for the borrowers in the first quartile of pre-2001 ROA distribution. All the regressions include firm fixed effects. The standard errors in parentheses are corrected for clustering at the industry-state level. *, **, and $* * *$ denote significance at the 10,5 , and 1 percent level, respectively.

\begin{tabular}{lcc}
\hline & Investments Ratio & Sales Growth \\
\hline Guarantee & $0.0255^{* * *}$ & $0.0524 * * *$ \\
& $(0.002)$ & $(0.008)$ \\
GuaranteexDependent & $0.0164 * * *$ & $0.0306 * * *$ \\
& $(0.003)$ & $(0.009)$ \\
GuaranteexDependent×LowROA & $0.0181 * * *$ & $0.0569 * *$ \\
& $(0.006)$ & $(0.028)$ \\
GuaranteexLowROA & 0.0055 & -0.0171 \\
& $(0.005)$ & $(0.026)$ \\
Firm controls & & \\
Firm FE & Yes & Yes \\
Adj. R-squared & Yes & Yes \\
Number of Obs. & 0.092 & 0.051 \\
\hline
\end{tabular}




\section{Table A4- Investment Ratio, across Banks' Reliance on Guaranteed Debt}

The sample is the two period borrower level matched panel. Investments Ratio is investments per euro of total assets. Ex-ante banks' reliance on guaranteed debt is the pre-2001 average of amount of bank debt as share of total assets. Guarantee is a dummy equal to one for years 1995 until 2000 and zero for years 2001 until 2006. Dependent is a dummy equal to one for borrowers with SBDep equal to one and is zero for borrowers with SBDep less than 10 percent. LowROA is a dummy equal to one for the borrowers in the first quartile of pre-2001 ROA distribution. All the regressions include firm fixed effects. The standard errors in parentheses are corrected for clustering at the industry-state level. *,**, and $* * *$ denote significance at the 10,5 , and 1 percent level, respectively.

\begin{tabular}{lcccc}
\hline & \multicolumn{3}{c}{ Quartiles of Ex-ante Banks' Reliance on Guarantees } \\
\hline Investment Ratio & 1 st & 2nd & 3rd & 4th \\
\hline Guarantee & $0.0233 * * *$ & $0.0234 * * *$ & $0.0260 * * *$ & $0.0292 * * *$ \\
GuaranteexDependent & $(0.004)$ & $(0.005)$ & $(0.004)$ & $(0.005)$ \\
& $0.0273 * * *$ & $0.0122^{* *}$ & $0.0187 * * *$ & 0.0086 \\
GuaranteexDependent×LowROA & $(0.005)$ & $(0.005)$ & $(0.005)$ & $(0.005)$ \\
& 0.0139 & $0.0238^{*}$ & -0.0004 & $0.0372 * * *$ \\
GuaranteexLowROA & $(0.013)$ & $(0.012)$ & $(0.011)$ & $(0.014)$ \\
& 0.0119 & -0.0008 & 0.012 & -0.0038 \\
& $(0.009)$ & $(0.009)$ & $(0.010)$ & $(0.012)$ \\
Firm controls & & & & Yes \\
Firm FE & Yes & Yes & Yes & Yes \\
Adj. R-squared & Yes & Yes & Yes & 0.081 \\
Number of Obs. & 0.117 & 0.08 & 0.095 & 7954 \\
\hline
\end{tabular}


Table A5- Sales Growth, across Banks' Reliance on Guaranteed Debt

The sample is the two period borrower level matched panel. Sales Growth is the yearly average rate of sales growth. Ex-ante banks' reliance on guaranteed debt is the pre-2001 average of amount of bank debt as share of total assets. Guarantee is a dummy equal to one for years 1995 until 2000 and zero for years 2001 until 2006. Dependent is a dummy equal to one for borrowers with SBDep equal to one and is zero for borrowers with SBDep less than 10 percent. LowROA is a dummy equal to one for the borrowers in the first quartile of pre-2001 ROA distribution. All the regressions include firm fixed effects. The standard errors in parentheses are corrected for clustering at the industry-state level. *,**, and *** denote significance at the 10,5 , and 1 percent level, respectively.

\begin{tabular}{lcccc}
\hline & \multicolumn{3}{c}{ Quartiles of Ex-ante Banks' Reliance on Guarantees } \\
\hline Sales Growth & 1st & 2nd & 3rd & 4th \\
\hline Guarantee & $0.0350^{* *}$ & $0.0545^{* * *}$ & $0.0711^{* * *}$ & $0.0486^{* * *}$ \\
& $(0.015)$ & $(0.014)$ & $(0.018)$ & $(0.016)$ \\
GuaranteexDependent & $0.0385^{* *}$ & 0.0243 & 0.0138 & $0.0515^{* *}$ \\
& $(0.017)$ & $(0.016)$ & $(0.019)$ & $(0.022)$ \\
GuaranteexDependent×LowROA & 0.0819 & -0.0136 & 0.067 & $0.1008^{*}$ \\
& $(0.054)$ & $(0.055)$ & $(0.049)$ & $(0.055)$ \\
GuaranteexLowROA & -0.0195 & 0.0161 & -0.0542 & 0.0005 \\
& $(0.054)$ & $(0.049)$ & $(0.046)$ & $(0.046)$ \\
Firm controls & & & & Yes \\
Firm FE & Yes & Yes & Yes & Yes \\
Adj. R-squared & Yes & Yes & Yes & 0.085 \\
Number of Obs. & 0.05 & 0.042 & 0.045 & 5260 \\
\hline
\end{tabular}




\section{Table A6 - Propensity Score Matching Results}

By applying a propensity score matching we estimate average treatment effect on treated, assuming savings banks dependent firms as treatment group and savings banks independent firms as the control group. Savings banks dependent borrowers are those with SBDep equal to one and is zero for borrowers with SBDep less than 10 percent. We use four nearest neighbors. The propensity scores are estimated by using a probit regression where the covariates are total assets, fixed assets, leverage, state and industry. All the variables are as defined in Table 1. The standard errors in parentheses are the analytical heteroskedasticity-consistent standard errors proposed by Abadi and Imbens (2006). *,**, and *** denote significance at the 10, 5 , and 1 percent level, respectively.

\begin{tabular}{lccccc}
\hline Propensity score matching & \multirow{2}{*}{ Full Sample } & \multicolumn{4}{c}{ Pre-2001 ROA Quartiles } \\
\cline { 1 - 4 } ATET & & 1st & 2nd & 3rd & 4th \\
\cline { 1 - 3 } Investment Ratio & $0.0192^{* * * *}$ & $0.0317^{* * *}$ & $0.0185^{* * *}$ & $0.0201^{* * *}$ & -0.0011 \\
& $(0.003)$ & $(0.006)$ & $(0.005)$ & $(0.005)$ & $(0.007)$ \\
Sales Growth & $0.0339^{* * *}$ & $0.0968^{* * *}$ & $0.0616^{* * *}$ & 0.0164 & $0.0362 * * *$ \\
& $(0.011)$ & $(0.029)$ & $(0.019)$ & $(0.016)$ & $(0.018)$ \\
\hline
\end{tabular}




\section{Table A7 - Placebo Tests, Micro-level}

The sample is the subset of the matched sample in the main analysis, split to two periods of 2001-2003 and 2004-2006. Therefore, Guarantee is a dummy equal to one for years 2001 until 2003 and zero for years 2004 until 2006. Dependent is a dummy equal to one for borrowers with SBDep equal to one and is zero for borrowers with SBDep less than 10 percent. All the other variables are as defined in Table 1. All the regressions include firm fixed effects. The standard errors in parentheses are corrected for clustering at the industry-state level. *, **, and *** denote significance at the 10,5 , and 1 percent level, respectively.

\begin{tabular}{lccc}
\hline & Investment Ratio & Sales Growth & $\begin{array}{c}\text { Technical } \\
\text { Efficiency }\end{array}$ \\
\hline Guaranty & $0.0101^{* *}$ & -0.0001 & $0.0067 * * *$ \\
GuaranteexDependent & $(0.004)$ & $(0.009)$ & $(0.001)$ \\
& -0.0015 & -0.0017 & 0.0006 \\
Firm controls & $(0.004)$ & $(0.011)$ & $(0.001)$ \\
Firm FE & & & \\
Adj. R-squared & Yes & Yes & Yes \\
Number of Obs. & 0.016 & Yes & Yes \\
\hline
\end{tabular}




\section{Table A8 - Placebo Tests, Macro-level}

The sample is the yearly industry level data on Exit. Dependent is a dummy which is equal to one for industries that are in the highest quartile of SBDep distribution and is zero for the others. Guarantee is a dummy equal to one for years between 2001 and 2003 and zero otherwise. The last column shows clustered standard errors in parentheses that are calculated at the industry-Guarantee level; otherwise we show un-clustered standard errors. ${ }^{*}, * *$, and $* * *$ denote significance at the 10,5 , and 1 percent level, respectively.

\begin{tabular}{lcc}
\hline & $\log ($ Exit $)$ & $\log ($ Exit $)$ \\
\hline GuaranteexDependent & -0.11 & -0.021 \\
& $(0.084)$ & $(0.100)$ \\
Log(Total No. Firms) & & $0.636^{* *}$ \\
& & $(0.274)$ \\
Sector FE & Yes & Yes \\
Year FE & Yes & Yes \\
Adj. R-squares & 0.986 & 0.988 \\
Number of Obs. & 78 & 78 \\
\hline
\end{tabular}




\section{Table A9 - Investments Ratio across TE Quartiles}

The sample is the two period borrower level panel. Investments Ratio is investments per euro of total assets. Guarantee is a dummy equal to one for years 1995 until 2000 and zero for years 2001 until 2006. Dependent is a dummy equal to one for borrowers with SBDep equal to one and is zero for borrowers with SBDep less than 10 percent. All the regressions include firm fixed effects. The standard errors in parentheses are corrected for clustering at the industrystate level. *, **, and $* * *$ denote significance at the 10,5 , and 1 percent level, respectively.

\begin{tabular}{lccccc}
\hline \multirow{2}{*}{ Investment Ratio } & \multirow{2}{*}{ Full Sample } & \multicolumn{4}{c}{ Pre-2001 TE Quartiles } \\
\cline { 3 - 6 } & & 1st & 2nd & 3rd & 4th \\
\hline Guarantee & $0.0268^{* * *}$ & $0.0354^{* * *}$ & $0.0190^{* * *}$ & $0.0277^{* * *}$ & $0.0239^{* * *}$ \\
GuaranteexDependent & $(0.002)$ & $(0.007)$ & $(0.005)$ & $(0.004)$ & $(0.003)$ \\
& $0.0212^{* * *}$ & $0.0228^{* * *}$ & $0.0263^{* * *}$ & $0.0124^{* * *}$ & $0.0160^{* * *}$ \\
& $(0.003)$ & $(0.008)$ & $(0.006)$ & $(0.005)$ & $(0.004)$ \\
Firm controls & & & & & \\
Firm FE & Yes & Yes & Yes & Yes & Yes \\
Adj. R-squared & Yes & Yes & Yes & Yes & Yes \\
Number of Obs. & 0.088 & 0.109 & 0.084 & 0.081 & 0.081 \\
& 32266 & 7346 & 7344 & 7344 & 7344 \\
\hline
\end{tabular}




\section{Table A10 - Sales Growth across TE Quartiles}

The sample is the two period borrower level panel. Sales Growth Rate is the yearly average rate of sales growth. Guarantee is a dummy equal to one for years 1995 until 2000 and zero for years 2001 until 2006. Dependent is a dummy equal to one for borrowers with SBDep equal to one and is zero for borrowers with SBDep less than 10 percent. All the regressions include firm fixed effects. The standard errors in parentheses are corrected for clustering at the industrystate level. *,**, and *** denote significance at the 10,5, and 1 percent level, respectively.

\begin{tabular}{lccccc}
\hline & Full Sample & \multicolumn{4}{c}{ Pre-2001 TE Quartiles } \\
\cline { 3 - 6 } Sales Growth & & $1 \mathrm{st}$ & 2nd & 3rd & 4th \\
\hline Guarantee & $0.0485^{* * *}$ & 0.0186 & $0.0779 * * *$ & $0.0691 * * *$ & $0.0418^{* * *}$ \\
& $(0.007)$ & $(0.027)$ & $(0.020)$ & $(0.011)$ & $(0.012)$ \\
GuaranteexDependent & $0.0447 * *$ & $0.0820 * * *$ & 0.0061 & 0.0207 & $0.0407 * *$ \\
& $(0.009)$ & $(0.029)$ & $(0.022)$ & $(0.015)$ & $(0.016)$ \\
Firm controls & & & & Yes & Yes \\
Firm FE & Yes & Yes & Yes & Yes & Yes \\
Adj. R-squared & Yes & Yes & Yes & 0.057 & 0.036 \\
Number of Obs. & 0.049 & 0.054 & 0.058 & 5332 & 5331 \\
\hline
\end{tabular}




\section{Table A11 - Investments Ratio after Dropping the Years Confounded by Agenda 2010}

The sample is the two period borrower level panel in which the observations for years 2003 and later are dropped. Guarantee is a dummy equal to one for years 1995 until 2000 and zero for years 2001 and 2002. Dependent is a dummy equal to one for borrowers with SBDep equal to one and is zero for borrowers with SBDep less than 10 percent. All the regressions include firm fixed effects. The standard errors in parentheses are corrected for clustering at the industry-state level. *, **, and $* * *$ denote significance at the 10,5 , and 1 percent level, respectively.

\begin{tabular}{|c|c|c|c|c|c|}
\hline \multirow[b]{2}{*}{ Investment Ratio } & \multirow{2}{*}{ Full Sample } & \multicolumn{4}{|c|}{ Pre-2001 ROA Quartiles } \\
\hline & & $1 \mathrm{st}$ & 2nd & $3 \mathrm{rd}$ & 4th \\
\hline \multirow[t]{2}{*}{ Guarantee } & $0.0211^{* * *}$ & $0.0272 * * *$ & $0.0195 * * *$ & $0.0210 * * *$ & $0.0169 * *$ \\
\hline & $(0.002)$ & $(0.005)$ & $(0.004)$ & $(0.004)$ & $(0.007)$ \\
\hline \multirow[t]{2}{*}{ GuaranteexDependent } & $0.0220 * * *$ & $0.0366^{* * *}$ & $0.0169 * * *$ & $0.0147 * * *$ & $0.0180 * *$ \\
\hline & $(0.003)$ & $(0.007)$ & $(0.005)$ & $(0.005)$ & $(0.007)$ \\
\hline Firm controls & Yes & Yes & Yes & Yes & Yes \\
\hline Firm FE & Yes & Yes & Yes & Yes & Yes \\
\hline Adj. R-squared & 0.066 & 0.117 & 0.06 & 0.054 & 0.039 \\
\hline Number of Obs. & 28162 & 7210 & 6872 & 7040 & 7040 \\
\hline
\end{tabular}




\section{Table A12 - Sales Growth after Dropping the Years Confounded by Agenda 2010}

The sample is the two period borrower level panel in which the observations for years 2003 and later are dropped. Guarantee is a dummy equal to one for years 1995 until 2000 and zero for years 2001 and 2002. Dependent is a dummy equal to one for borrowers with SBDep equal to one and is zero for borrowers with SBDep less than 10 percent. All the regressions include firm fixed effects. The standard errors in parentheses are corrected for clustering at the industry-state level. *, **, and $* * *$ denote significance at the 10, 5, and 1 percent level, respectively.

\begin{tabular}{|c|c|c|c|c|c|}
\hline \multirow[b]{2}{*}{ Sales Growth } & \multirow{2}{*}{ Full Sample } & \multicolumn{4}{|c|}{ Pre-2001 ROA Quartiles } \\
\hline & & $1 \mathrm{st}$ & 2nd & $3 \mathrm{rd}$ & 4th \\
\hline \multirow[t]{2}{*}{ Guarantee } & $0.0506^{* * *}$ & 0.0327 & $0.0548 * * *$ & $0.0644 * * *$ & $0.0482 * *$ \\
\hline & $(0.009)$ & $(0.025)$ & $(0.016)$ & $(0.017)$ & $(0.021)$ \\
\hline \multirow[t]{2}{*}{ GuaranteexDependent } & $0.0516^{* * *}$ & $0.0954 * * *$ & $0.0577 * * *$ & 0.0119 & $0.0428 *$ \\
\hline & $(0.011)$ & $(0.030)$ & $(0.022)$ & $(0.019)$ & $(0.024)$ \\
\hline Firm controls & Yes & Yes & Yes & Yes & Yes \\
\hline Firm FE & Yes & Yes & Yes & Yes & Yes \\
\hline Adj. R-squared & 0.052 & 0.055 & 0.06 & 0.039 & 0.067 \\
\hline Number of Obs. & 19890 & 5069 & 4854 & 5030 & 4937 \\
\hline
\end{tabular}




\section{Table A13 - Technical Efficiency after Dropping the Years Confounded by Agenda 2010}

The sample is the two period borrower level panel in which the observations for years 2003 and later are dropped. Guarantee is a dummy equal to one for years 1995 until 2000 and zero for years 2001 and 2002. Dependent is a dummy equal to one for borrowers with SBDep equal to one and is zero for borrowers with SBDep less than 10 percent. All the regressions include firm fixed effects. The standard errors in parentheses are corrected for clustering at the industry-state level. *, **, and $* * *$ denote significance at the 10,5 , and 1 percent level, respectively.

\begin{tabular}{lc}
\hline & Full Sample \\
Technical Efficiency & $-0.0081^{* * *}$ \\
\hline Guaranty & $(0.001)$ \\
GuaranteexDependent & $-0.0026^{* * *}$ \\
& $(0.001)$ \\
Firm controls & \\
Firm FE & Yes \\
Adj. R-squared & Yes \\
Number of Obs. & 0.401 \\
\hline
\end{tabular}




\section{Appendix B: Efficient Frontier Estimation}

To estimate technical efficiency, we follow Greene (2008). In short, we estimate a stochastic production frontier and estimate the technical inefficiencies for each observation as the distance to this frontier. In particular, considering equation (3), we assume a parametric production function where $y$ is total sales, and the vector $\mathbf{x}$ includes fixed assets, as the usual measure of capital in this literature and wages as a measure of labor, all in logs. We estimate equation (3) in each year for the cross section of the firms in our sample.

$$
y_{i}=\mathrm{B}^{\prime} \mathbf{x}_{\mathbf{i}}+v_{i}-u_{i}
$$

In equation (3), $\mathrm{B}^{\prime} \mathbf{x}_{\mathbf{i}}+v_{i}$ denotes to the optimal frontier goal attainable by individual firm. The first term, $\mathrm{B}^{\prime} \mathbf{x}_{\mathbf{i}}$, is the deterministic part and the second term, $v_{i}$, is the stochastic part which embodies all measurement errors, any statistical noise and also random variation of frontier across firms. These two parts together, therefore, form the stochastic frontier. Hence the actual output's distance to this frontier is coined as technical inefficiency and is measured by the estimated $u_{i}$. In fact, $u_{i}$ represents the proportion by which $y$ falls short of the frontier. Technical efficiency is then defined to be $\exp \left(-u_{i}\right)$ for each observation in the cross sectional sample. To be able to estimate such a model, one needs to make assumptions about the distributional forms of $v_{i}$ and $u_{i}$. The most widely accepted distributional assumptions in the efficiency estimation literature are zero mean normally distributed $v_{i}$ and half-normally distributed $u_{i}$. We also let both of these terms to be heteroskedastic with the variances being a linear function of firm size. We estimate the inefficiencies using maximum likelihood estimation approach detailed in Greene (2008), and use these estimates to calculate technical efficiency measures. 
